\title{
Bioethanol from macroalgae: Prospects and challenges
}

\author{
T.V. Ramachandra ${ }^{a, b, *}$, Deepthi Hebbale ${ }^{a, b}$ \\ ${ }^{a}$ Energy \& Wetlands Research Group, Centre for Ecological Sciences, Indian Institute of Science, Bangalore, 560012, India \\ ${ }^{\mathrm{b}}$ Centre for Sustainable Technologies, Indian Institute of Science, Bangalore, 560012, India
}

\section{A R T I C L E I N F O}

\section{Keywords:}

Bioenergy

Biofuel

Enteromorpha intestinalis

Macroalgae

Seaweeds

Ulva lactuca

\begin{abstract}
A B S T R A T
Burgeoning dependence on fossil fuels for transport and industrial sectors has been posing challenges such as depletion of fossil fuel reserves, enhanced greenhouse gas (GHG) footprint, with the imminent changes in the climate, etc. This has necessitated an exploration of sustainable, eco-friendly and carbon neutral energy alternatives. Recent studies on biofuels indicate that algal biomass, particularly from marine macroalgae (seaweeds) have the potential to supplement oil fuel. Marine macroalgae are fast growing and carbohydrate rich biomass having advantage over other biofuel feedstock in terms of land dependence, freshwater requirements, not competing with food crops, which were the inherent drawback of the first- and second-generation feedstock. The present communication reviews the macroalgal feedstock availability, screening and selection of viable feedstock based on the biochemical composition, process involved, scope and opportunities in bioethanol production as well as technology interventions. The prospect of bioethanol production from algal feedstock of Central West Coast of India has been evaluated taking into account challenges (feedstock sustenance, technical feasibility, economic viability) in order to achieve energy sustainability. The green algae exhibited growth during all seasons and highest total carbohydrate was recorded from green seaweed Ulva lactuca (62.15 $\pm 12.8 \%)$. Elemental (CHN) analyses of seaweed samples indicate $25.31-37.95 \%$ of carbon, $4.52-6.48 \%$ hydrogen and $1.88-4.36 \%$ Nitrogen. Highest carbon, hydrogen and nitrogen content were recorded respectively from G.pusillum (C: $37.95 \%$ ), G. pusillum (H: $6.48 \%$ ) and E.intestinalis (N: 4.36\%). Green seaweeds are rich in cellulose content ( $>10 \%)$ compared to other seaweeds (2-10\%). Higher cellulose content was estimated in U.lactuca (14.03 $\pm 0.14 \%)$, followed by $E$. intestinalis $(12.10 \pm 0.53 \%)$ and C.media $(10.53 \pm 0.17 \%)$. Cellulose is a glucan present in green seaweeds, which can easily be hydrolysed through enzyme and subsequently fermented to produce bioethanol. Lower sugar removal in acid hydrolysate neutralization process $\left(\mathrm{Na}_{2} \mathrm{CO}_{3}\right)$ was recorded in U.lactuca (39.8\%) and E.intestinalis (14.7\%). Highest ethanol yield of $1.63 \mathrm{~g}$ and $0.49 \mathrm{~g}$ achieving $25.8 \%$ and $77.4 \%$ efficiency in SHF (Separate Hydrolysis and Fermentation) and SSF (Simultaneous Saccharification and Fermentation) process respectively was recorded for green alga E. intestinalis.
\end{abstract}

\section{Introduction}

Fossil fuels such as oil, coal and natural gas are the major commercial energy sources and about $87 \%$ of global $\mathrm{CO}_{2}$ emitted due to the anthropogenic activities [1,2] are contributed by utilization of coal (43\%), oil (36\%) and natural gas (20\%). Earth endows finite source of oil reserve and its increased consumption in several sectors has led to increased oil production, exerting pressure on the reserves which is apprehended to peak and no longer suffice the world's demand with the fast dwindling stock [3]. Rising population with higher consumption levels coupled with a fast pace of development have spurred higher exploitation of fossil fuels leading to the escalating prices and resultant greenhouse gases (GHGs) posing problems for planet's climatic stability [4-6]. It is imperative to ensure energy security through the sustainable alternative energy sources [7,8]. Globally, nations are actively addressing the issues concerning greenhouse gases and peak oil crisis through several mitigation measures such as; energy conservation, fuel substitution, incentives for the use of unconventional and renewable oil, and policy reforms such as carbon tax [8]. Therefore, the current focus is on carbon neutral renewable sources, notably photovoltaic, wind,

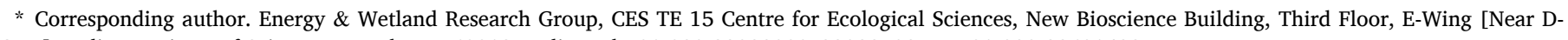
Gate], Indian Institute of Science, Bangalore, 560012, India. Tel.: 91-080-22933099/22933503;Fax: 91-080-23601428.

E-mail addresses: cestvr@ces.iisc.ernet.in, energy.ces@iisc.ac.in, tvr@iisc.ac.in (T.V. Ramachandra), deepthih@iisc.ac.in (D. Hebbale).

URL: http://ces.iisc.ernet.in/energy (T.V. Ramachandra). 
hydrogen, etc. These alternative sources were useful in addressing the electricity requirement, but the exploration for viable alternatives to oil in order to meet the requirement of transport sector, etc. is quintessential. Despite the existence of possible solutions such as renewable resources, energy efficient products (CFLs and LEDs) have not been widely adopted due to market barriers. Wind power contributes $2.5 \%$ of world electricity output and are weather dependent, susceptible to geographic and climatic changes [9,10]. Dependency on conventional generation coupled with the depleting stock and the enhanced environmental awareness in the public have been the major constraints faced by the land based energy systems $[11,12]$. Nuclear power witnessed $2 \%$ growth in Europe, but encountered resistance with respect to disposal of waste, safety during nuclear accident and declining global uranium stocks. Nuclear disaster at Fukushima Daiichi nuclear power plant in 2011 [13], led Germany to rethink its energy policy [14].

India has been the 3rd largest energy consumer surpassing Russia, China and USA and about $80 \%$ of India's energy consumption was contributed by imported crude oil [15], which was estimated to be 213.93 Million Metric Ton (MMT) in the year 2016-17. This is attributed to the poorly endowed natural reserve of hydrocarbon in India, however crude oil production in India is about 36.01 MMT, from the $0.3 \%$ oil reserves [15]. India is emerging as the fastest growing economy next to China with the growing energy demand, burgeoning population (at $1.58 \%$ annual) and dwindling stock of fossil fuel in next few decades, it is challenging to support this growing economy demand [16]. The total $\mathrm{CO}_{2}$ emission in India accounts for $965.9 \mathrm{Tg} / \mathrm{yr}$, with electricity generation $(343 \mathrm{Tg} / \mathrm{yr})$ and transport $(246.23 \mathrm{Tg} / \mathrm{yr})$ sectors as the major contributors [17]. The higher level of $\mathrm{CO}_{2}$ emissions necessitates implementation of efficient management strategies to mitigate changes in climate [18]. The new renewable energy resources are being explored to meet the energy demand in all sectors and also research is underway to address the intermittency problems associated with wind and solar based energy systems [19-21].

In this context, studies have shown that biofuels are emerging as promising alternative to liquid fuels. Realizing the potential of biomass, different technologies have evolved towards the conversion of biomass into fuels, popularly known as biofuels [22-24]. Produced from renewable plant sources or other organic wastes, biofuels have the advantages of cutting down carbon emission and dependency on oil [25]. In India, around $80 \%$ of rural energy [26] is met by biomass energy consumption, in the form of firewood, agriculture residues, cow dung cake and other natural feedstock [24,27,28]. Fig. 1 represents the share of each country in the global bioethanol production, which highlights that India's share is only 2\% [29] despite burgeoning demand for fossil fuel. This emphasizes the need for augmentation with the viable indigenous alternative feedstock to minimize fossil fuel dependence.

Biofuel from first generation feedstock involved food crops like corn and sugarcane which were exploited for biofuel production over three decades, but this technique encountered resistance due to the limited stock and competition with food crops [25]. The inadequacy of first generation feedstock in augmenting the growing energy demand led to the evolution of second generation feedstock involving lignocellulose biomass (Fig. 2). However, biofuel from second-generation feedstock also failed, due to the difficulty in scaling up and process technology involved in the cost-intensive delignification process [30]. Due to this, the cost of production of cellulosic ethanol is two to three fold higher than the price of corn grain ethanol [31]. In the US, it was seen that, the fossil energy required to produce bioethanol from corn, grain, soybean and wood biomass was more than the energy content of the biofuel, while sufficing only $12 \%$ of gasoline and $6 \%$ of the diesel demand. Though first and second generation feedstock are explored for biofuel production and assessed for carbon sequestration, environmental impacts and production potential only marginally complies with various other sustainability criteria's such as; disruption of global food supply, soil erosion, extensive usage of fertilizers, conversion of ecologically vulnerable wetlands, rainforests, peat lands, savannas into energy crop lands contributing to several magnitude of $\mathrm{CO}_{2}$ [32,33]. GHGs footprint of major cities in India [34], recorded aggregation of carbon dioxide equivalent emission of GHGs in the range of $13,734.59-38,633.2 \mathrm{Gg}$, with transportation being one of the major sector next to the energy generation. Emergence of a strong global biofuel feedstock is expected to realize a positive balance between energy and ecological footprints [35].

Table 1 illustrates the prospects of algal biomass emerging as an ideal alternative to the first and second generation $[37,38]$. Though, algae is being utilized as an energy feedstock since 1950s [26], the oil crisis of 1970's spurted the research [39]. Algal feedstock do not require prime agricultural land and can be grown in fresh water, wastewater [40] and saline waters with zero nutrient input and non-interference with the land used for food production [38,41]. Algal biomass have higher photosynthetic efficiency (up to $5 \%$ ) as compared to terrestrial biomass (1.8-2.2\%) [42], and require for their growth light, carbon dioxide and nutrients (such as nitrogen, phosphorus, potassium, etc.), which are maintained through continuous flow of water [42]. Algae have a higher yield per unit area compared to terrestrial plants e.g. brown algae under the cultured condition, yields $\sim 13.1 \mathrm{~kg}$ dry weight $/ \mathrm{m}^{2}$ over 7 months as compared to sugarcane yield of $\sim 10 \mathrm{~kg}$ dry weight $/ \mathrm{m}^{2} / \mathrm{yr}$ [43]. Algae based on their morphology and size are grouped into micro and macroalgae [29]. Microalgae accumulate large quantities of neutral lipids

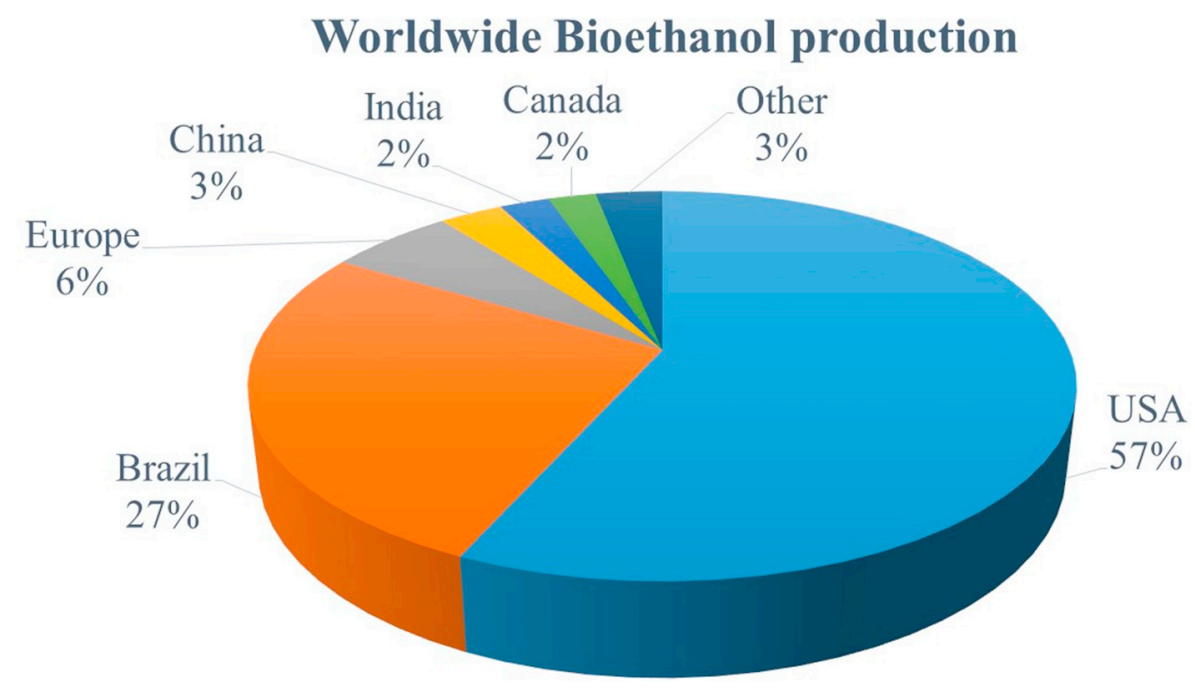

Fig. 1. Worldwide bioethanol production. 


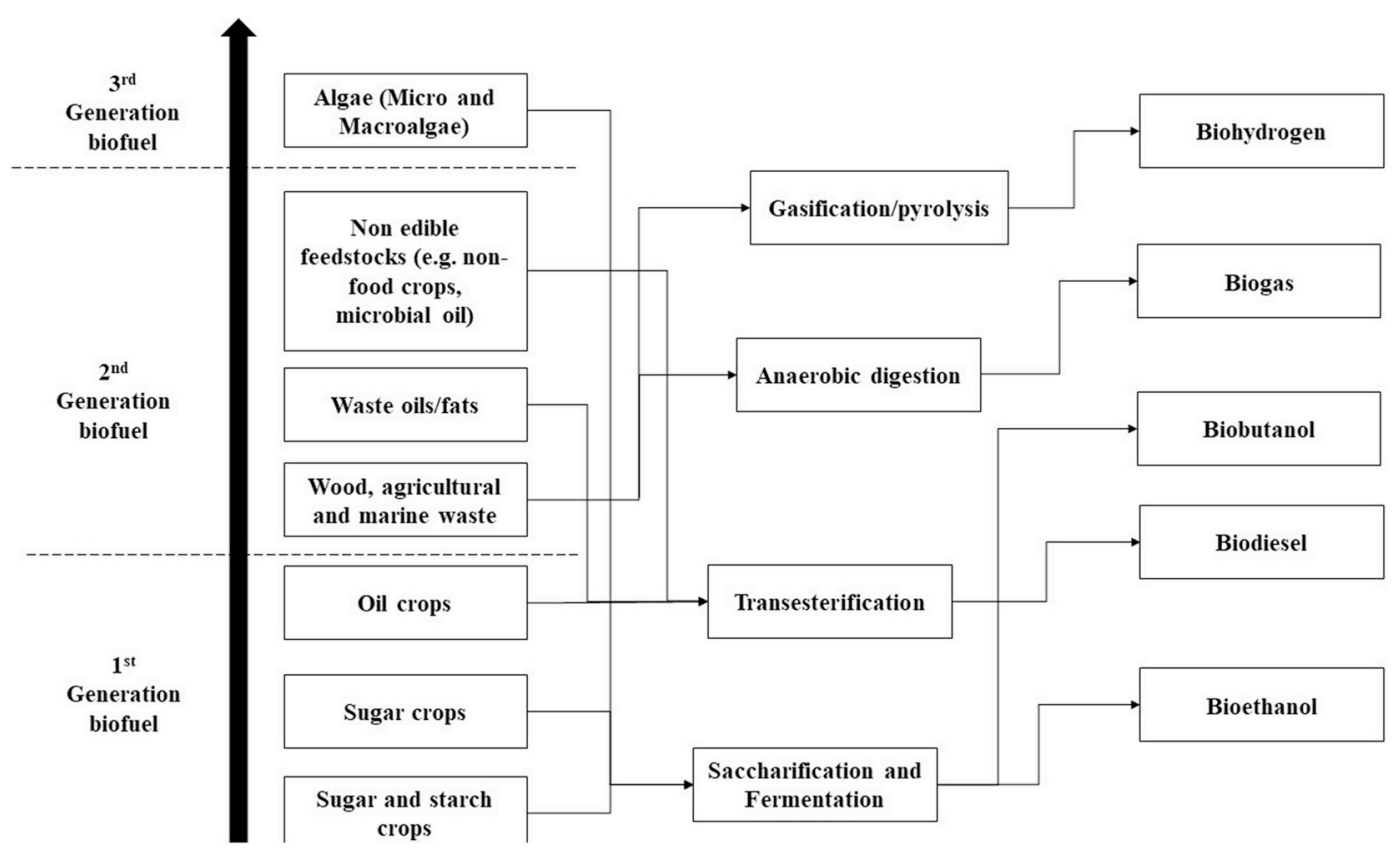

Fig. 2. Evolution of biofuel production from feedstocks and technologies.

Table 1

Yield and Ethanol production of First, Second and Third generation feedstocks.

\begin{tabular}{llll}
\hline Biofuel & Crop & Yield(ton/ha/yr) & Ethanol (litres/ha/yr) \\
\hline \multirow{2}{*}{ First generation } & Sugarcane & $50-90$ & $3500-8000$ \\
& Sweet sorghum & $45-80$ & $1750-5300$ \\
& Sugar beet & $15-50$ & $1350-5500$ \\
& Fodder Beet & $100-200$ & $4400-9350$ \\
& Wheat & $1.5-2.1$ & $510-714$ \\
& Barley & $1.2-2.5$ & $300-625$ \\
& Rice & $2.5-5.0$ & $1075-2150$ \\
& Irish potatoes & $10-25$ & $1110-2750$ \\
& Cassava & $10-65$ & $1700-11,050$ \\
& Sweet potatoes & $8-50$ & $1336-8350$ \\
& Grapes & $10-25$ & $1300-3250$ \\
Second generation & Nipa palm & & $2300-8000$ \\
& Maize & $1.7-5.4$ & $600-1944$ \\
Third generation & Sorghum & $1.0-3.7$ & $350-1295$ \\
& Algal biomass & 730 & 23400 \\
\hline
\end{tabular}

Source: [36].

which serves as raw material for biodiesel production [44,45], whereas macroalgae are carbohydrate rich biomass which are useful for bioethanol production. Large scale cultivation of macroalgae in Korea reveals an uptake of 8-10 tonne $\mathrm{CO}_{2}$ per hectare [42].

\subsection{Potential macroalgal feedstock available}

Marine macroalgae or seaweeds establish on hard substratum and grow luxuriantly along nutrient rich coastal zone (Fig. 3). One of the richest seaweed resources in the world is in Nova Scotia/Gulf of St. Lawrence area [46]. Global seaweed distribution can be summarized as: (i) Least flora $<200 \mathrm{Spp}$ in latitudes $>60^{\circ}$ in both hemispheres, (ii) Moderate flora of 600-700 spp. that occur throughout warm and cold tropical and temperate regions, (iii) Highest flora of 900-1100 spp. occur in four regions Southern Australia, Mediterranean, Japan and Philippines.

Seaweed resources and their uses are well established across regions in the world. Red seaweeds are mostly utilized for extraction of hydrocolloid valuing \$585 million [47] and source of food (e.g. Salads) valuing $\$ 5$ billion [48] with Asia as its prime market [43]. Cultivation of macroalgae is a promising option as seventy percent of the Earth surface is covered by water $[39,42,49,50]$, therefore in order to satisfy these industrial demands, macroalgae are cultivated in large scale, mainly of the genus Laminaria, Undaria, Poryphyra, Eucheuma, Enteromorpha and Gracilaria representing $76 \%$ of total macroalgae aquaculture production [51].

In recent years, algal genera of Kappaphycus, Gelidium, Gracilaria, Sargassum, Laminaria and Ulva (Fig. 2), are the promising potential feedstock for biofuel production in addition to the value added products for phycocolloids extraction, human food, cosmetics, fertilizer and other chemicals $[52,53]$. These algal feedstock have been chosen considering the availability and assessment of resources around the globe, ease of cultivation and harvesting. However, there is still scope to assess other potential macroalgal species based on their availability, biochemical composition and prospects for cultivation.

\subsection{Bioethanol production from macroalgal feedstock}

Bioethanol from algal biomass is a sustainable and eco-friendly option of renewable biofuel production [39]. Macroalgae or seaweed, saltwater thriving algae have proved to be the viable biofuel feedstock [54] for sustainable biofuel production as it avoids the competition with fresh water, food crops or cultivable land [39,55]. Seaweeds are multicellular marine macroalgae, broadly grouped as green, brown and red based on the pigment present in the thallus. Seaweed consists of carbohydrates (Table 2), which are converted to bioethanol by appropriate microorganisms such as yeast or bacteria. The common processes involved in ethanol production are (i) pretreatment, (ii) hydrolysis and (iii) fermentation.

\subsubsection{Pretreatment and hydrolysis for extraction of macroalgal sugar}

Different types of biomass contain different amounts of sugars and the complexity of the biomass is reflected between structural and carbohydrate components [62,63]. Plant biomass is mostly composed of lignin (13.6-28.1\%), cellulose (40.6-51.2\%) and hemicellulose (28.5-37.2\%) biopolymer [64], which serves as raw material for production of fuels. However, critical step involved in biofuel production is the conversion of biomass to sugars [65]. It is therefore important to carefully choose the pretreatment process based on the biomass and an optimal pretreatment process towards better yield of sugar with the low energy input [66]. 


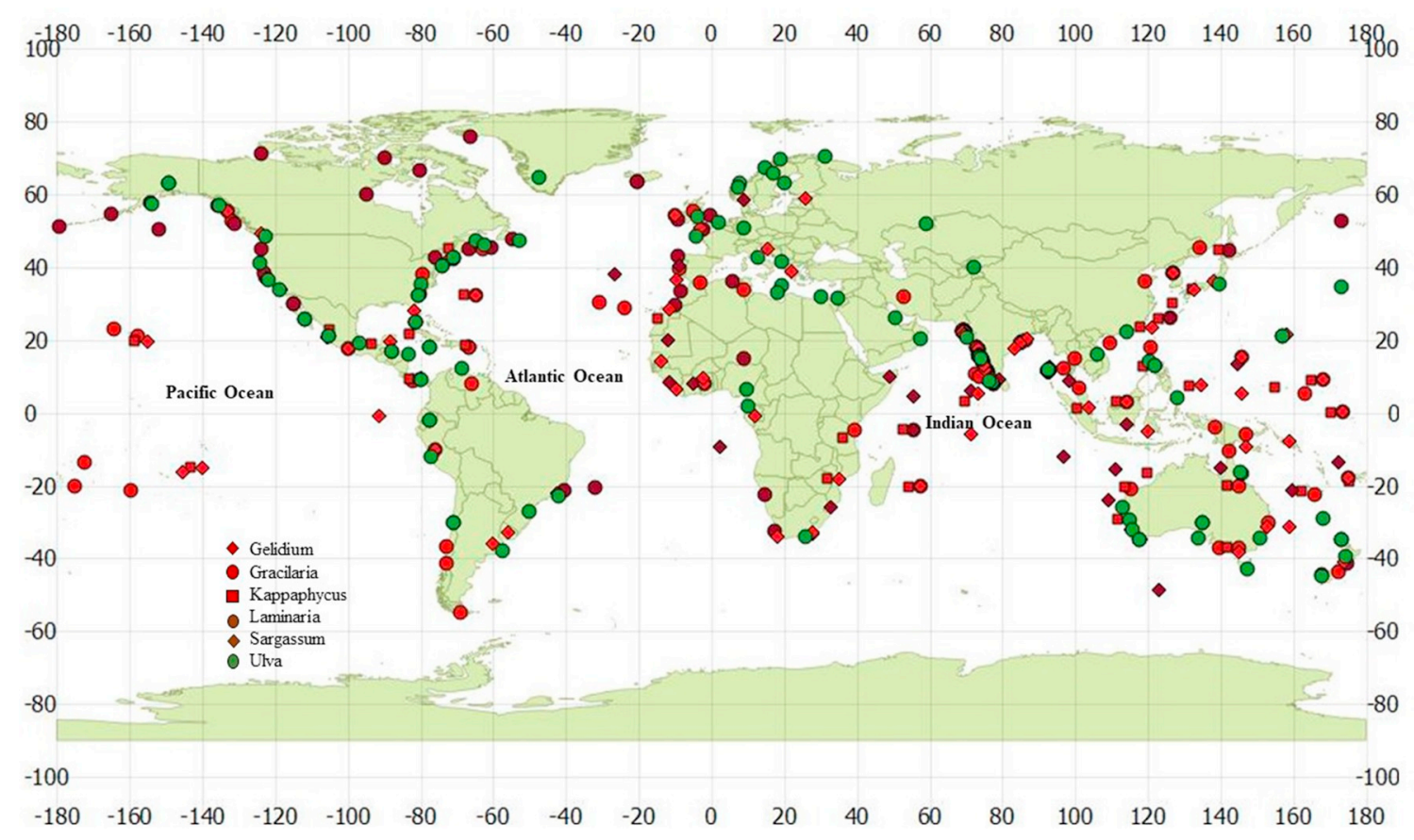

Fig. 3. Prominent coastal regions of the world rich in seaweed resources and potential feedstock for bioethanol production.

Pretreatment involves physical, chemical and biological (or combinatorial) process to expose the cell constituents and cell wall materials of feedstock [67]. Physical pretreatment involves reduction in size of the feedstock to increase the surface area for better transport of acid/base catalysts, enzymes and steam to the fibers (cellulose) [68]. Chemical pretreatment involves dilute acid, alkaline, ammonia, organo solvent and other chemicals. Biological pretreatment involves microorganisms like bacteria and fungi (rich in cellulase enzyme) to degrade the biomass and release the sugars [69]. Integrated pretreatment involves combination of all the process such as acid catalyzed steam explosion, ammonium fiber explosion (AFEX), acid pretreated enzyme hydrolysis etc [66].

First generation biomass is starch based and requires no stringent pretreatment conditions to extract sugar, whereas lignocellulose biomass is complex in structure due to the presence of biopolymer lignin that embeds cellulose in a matrix resulting in a higher degree of polymerization and crystallization, which is the main factor responsible for recalcitrance [66,70-72] requiring a high cost for delignification process [73]. Therefore, the process of sugar extraction requires severe pretreatment conditions such as steam explosion at $200^{\circ} \mathrm{C}$ [74], at $121^{\circ} \mathrm{C}$ [75], AFEX, Sulphite pretreatment to overcome recalcitrance of lignocellulose (SPORL) [31], pressurized steam liquefaction [76]. It is seen that alkaline based pretreatment is effective in solubilizing significant portion of lignin from lignocellulose biomass [69]. Lignin was removed from cotton stalk pretreated using sodium hydroxide at high temperature and $96 \%$ fermentable sugars were recovered [77,78]. Around 11.4 MMT cotton plant wastes available in India, can generate 3533 billion litres of ethanol considering $90 \%$ fermentation efficiency [78]. Removal of $89 \%$ lignin and $69.77 \%$ hemicellulose in rice husk was achieved through wet air oxidation pretreatment method [79]. Hydrothermal pretreatment of wheat straw was carried out and viewed under scanning electron microscope (SEM), which reveal partial de-fibration of the lignin fibers due to pretreatment, whereas in delignification process lignin appears as layer of globular deposits exposing the cellulose structure [71].

Compared to this, macroalgae with the large concentration of structural polysaccharides (Table 3) and low lignin contents [80] requires mild and low-cost processes for extraction of sugars. The most widely used chemical pretreatment method for macroalgal biomass is dilute acid (Table 4), as it solubilizes hemicellulose and exposes cellulose fibers for further enzyme hydrolysis [68]. The energy consumed in acid pre-treatment is comparatively low as compared to other pre-treatments and higher sugar yields are achieved [69]. Dilute acid concentration for hydrolysis varies based on the feedstock, listed in Table 3. However, limitation of dilute acid pretreatment is the formation of Hydroxymethyl furfurals (HMF) and Levulinic acid (LA) resulting from the degradation of sugars that inhibit the subsequent process (fermentation) in ethanol production [81,82]. These inhibitors are mitigated by neutralization process before fermentation $[83,84]$ or by employing other sustainable alternatives such as biological pretreatment: enzyme hydrolysis [53,85-94].

Enzyme hydrolysis of cellulose is carried out efficiently by cellulolytic (cellulase) enzyme, which is comprised of exo-, endo-glucanases and cellobiase ( $\beta$ - D-glucosidase) enzymes [71]. Endoglucanases cleave cellulose at random sites of $\beta$-1, 4-bond and form free reducing ends and short-chain oligosaccharides [84] Exoglucanases cleaves the accessible ends of cellulose molecules to liberate glucose and cellobiose. $\beta$ D-glucosidase hydrolyses soluble cellobiose and other cellodextrin to produce glucose molecules [95]. Enzyme conversion is substrate specific without any by-product formation. The process could be enhanced [7], by exposing the cellulose fibres through pre-treatment using acid. Enzymatic hydrolysis disintegrates the cellulose and hemicellulose into simple sugars [96]. Along with this, depolymerization of xylan (polysaccharide composed of xylose) can be achieved by dilute-acid pretreatment [88] with about $64 \%$ xylose conversion efficiency. Pretreatment techniques include high thermal liquefaction process (HTLP) [97], alkali pretreatment, $\mathrm{CaO}$, Ozonolysis, etc. However it was seen that the acid treated biomass was more susceptible for enzyme attack than HTLP, $\mathrm{NaOH}, \mathrm{CaO}$ and other pretreatment [87].

Algal cell wall is composed of cellulose I $\alpha$ (triclinic crystalline form) unlike the cellulose I $\beta$ (monoclinic crystalline form) in plant cell wall. Cellulose I $\alpha$ consists of weaker hydrogen bonds resulting from spatial arrangement of individual cellulose chains, resulting in easy access to endocellulases enzymes during enzyme hydrolysis [98]. Most common categories of enzymes considered for cell wall depolymerization are cellulases, hemicellulases and accessory enzymes [99], produced from wood-rot (soft rot) fungi such as Trichoderma, Penicillium, and Aspergillus [100]. The production costs of these enzymes are relatively higher. 
Table 2

Detailed characteristics of different types of Seaweeds.

\begin{tabular}{|c|c|c|c|}
\hline Characteristics & Green seaweed & Red seaweed & Brown seaweed \\
\hline $\begin{array}{l}\text { Number of } \\
\text { species } \\
\text { recorded }\end{array}$ & $6032^{\mathrm{a}}$ & $7105^{\mathrm{b}}$ & $2039^{c}$ \\
\hline Habitat & $\begin{array}{l}\text { Freshwater and } \\
\text { Marine }\end{array}$ & Strictly marine & Strictly marine \\
\hline $\begin{array}{l}\text { Photosynthetic } \\
\text { pigment } \\
\text { present }\end{array}$ & $\begin{array}{l}\text { Chlorophyll } a, b \text {, } \\
\text { carotene and } \\
\text { Xanthophyll }\end{array}$ & Phycoerythrin & Fucoxanthin \\
\hline $\begin{array}{l}\text { Photosynthetic } \\
\text { rate }(\mu \mathrm{mol} \\
\left.\mathrm{CO}_{2} / \mathrm{h}\right) \mathrm{g} / \text { dry }\end{array}$ & 30 to 1786 & 20-1808.7 & $100-500$ \\
\hline $\begin{array}{l}\text { Productivity } \\
\text { [dry g/(m }{ }^{2} \\
\text { year })]\end{array}$ & 7100 & $3300-11300$ & $3300-11300$ \\
\hline $\begin{array}{l}\text { Nature of cell } \\
\text { wall }\end{array}$ & $\begin{array}{l}\text { Cellulose, pectin } \\
\text { rarely hemi- } \\
\text { cellulose }\end{array}$ & $\begin{array}{l}\text { Cellulose and pectic } \\
\text { material with } \\
\text { polysulphate esters }\end{array}$ & $\begin{array}{l}\text { Cellulose with } \\
\text { alginic acid and } \\
\text { fucocinic acid }\end{array}$ \\
\hline Sexuality & $\begin{array}{l}\text { Isogamy to } \\
\text { oogamy }\end{array}$ & $\begin{array}{l}\text { Advanced and } \\
\text { complex } \\
\text { (oogamous) }\end{array}$ & Isogamy to oogamy \\
\hline $\begin{array}{l}\text { No. of flagella } \\
\text { and their } \\
\text { insertion }\end{array}$ & $\begin{array}{l}2 \text { or } 4 \text {, equal } \\
\text { anterior, } \\
\text { whiplash }\end{array}$ & Absent & $\begin{array}{l}\text { Only in } \\
\text { reproductive cells, } \\
2 \text { unequal, lateral } \\
\text { whiplash and tinsel }\end{array}$ \\
\hline Cell structure & Eukaryotic & Eukaryotic & Eukaryotic \\
\hline Phycolibins & Absent & $\begin{array}{l}\text { Allophycocyanin, r- } \\
\text { Phycoerythrin } \\
\text { r-Phycocyanin }\end{array}$ & Absent \\
\hline Carotenoids & $\begin{array}{l}\alpha-, \beta-, \gamma- \\
\text { carotene }\end{array}$ & $\alpha$-, $\beta$ - carotene & $\alpha-, \beta-, \varepsilon$ - carotene \\
\hline Xanthophylls & $\begin{array}{l}\text { Lutein } \\
\text { Prasinoxanthin }\end{array}$ & Lutein & $\begin{array}{l}\text { Fucoxanthin, } \\
\text { Violaxanthin, } \\
\text { Diadinoxanthin, } \\
\text { Heteroxanthin, } \\
\text { Vacheriaxanthin }\end{array}$ \\
\hline $\begin{array}{l}\text { Carbohydrate } \\
\text { (\%) }\end{array}$ & $30-60$ & $30-50$ & $20-30$ \\
\hline Protein (\%) & $10-20$ & $6-15$ & $10-15$ \\
\hline Lipid (\%) & $1-3$ & $0.5-1.5$ & $1-2$ \\
\hline Ash (\%) & $13-22$ & $5-15$ & $14-28$ \\
\hline $\begin{array}{l}\text { Photosynthetic } \\
\text { reserve* } \\
\text { (Stored food) }\end{array}$ & Starch & $\begin{array}{l}\text { Floridean starch } \\
\text { (intermediate } \\
\text { between true starch } \\
\text { and dextrin) }\end{array}$ & $\begin{array}{l}\text { Laminarin and } \\
\text { mannitol } \\
\text { (hexahydride } \\
\text { alcohol) }\end{array}$ \\
\hline
\end{tabular}

Source: $[50,54,56-61]$.

Table 3

Sugar profile of Macroalgae.

\begin{tabular}{|c|c|c|c|}
\hline & Green seaweeds & Red seaweeds & Brown seaweeds \\
\hline $\begin{array}{l}\text { Structural } \\
\text { polysaccharide }\end{array}$ & Cellulose & $\begin{array}{l}\text { Cellulose, } \\
\text { lignin }\end{array}$ & Cellulose, Alginate \\
\hline $\begin{array}{l}\text { Storage } \\
\text { polysaccharide }\end{array}$ & $\begin{array}{l}\text { Starch, Ulvan, } \\
\text { Mannan }\end{array}$ & $\begin{array}{l}\text { Agar, } \\
\text { Carrageenan }\end{array}$ & Fucoidan, laminarin \\
\hline Monosaccharides & $\begin{array}{l}\text { Glucose, } \\
\text { Mannose, } \\
\text { Rhamnose, } \\
\text { Xylose, Galactose }\end{array}$ & $\begin{array}{l}\text { Glucose, } \\
\text { Galactose, } \\
\text { Agarose }\end{array}$ & $\begin{array}{l}\text { Glucose, Galactose, } \\
\text { Fucose, Xylose }\end{array}$ \\
\hline Sugar alcohol & & & Mannitol \\
\hline Sugar Acid & $\begin{array}{l}\text { Uronic acid, } \\
\text { Glucuronic acid }\end{array}$ & & $\begin{array}{l}\text { Uronic acid, } \\
\text { Mannuronic acid, } \\
\text { Glucuronic acid, } \\
\text { Alginic acid }\end{array}$ \\
\hline
\end{tabular}

Source [47-50]:

Commercial industrial enzymes are produced from aerobic fungi Trichoderma reesei, which produces over $100 \mathrm{~g}$ per liter of crude cellulase enzyme with higher specific activity, achieved by genetic engineered strains [101]. Most common enzymes employed for seaweed hydrolysis are commercial enzymes such as Cellulase, Celluclast $1.5 \mathrm{~L}$, Viscozyme L, Novozyme 188, Termamyl 120 L, $\beta$-glucosidase, Multifect, Meicelase,
Amyloglucosidase etc operated at $\mathrm{pH}$ 4.5-5.5 and temperature $35-55^{\circ} \mathrm{C}$, incubation time varies based on the algal feedstock $[56,71,89$, 90,102-109].

Cellulase producing microbes have been screened and isolated from various sources such as soil from forest and nature reserves, hot water springs, marine bacteria [90] compost, sewage, animal manure and bovine rumen [91]. Enzymatic hydrolysis has been done conventionally at $<50{ }^{\circ} \mathrm{C}$, resulting in lower sugar yield [95]. Therefore, research is under progress for isolating efficient cellulolytic enzyme systems from a wide variety of bacteria, fungi, aerobes, anaerobes, mesophiles, thermophiles and thermo-stable microbes $[92,93,96]$ which can overcome low sugar yield for biofuel production. Cellulase from thermophilic and psychrophilic microbes are preferred as they are resistant to high and low temperatures respectively [91]. Thermo-stable enzymes increase solubility of reactants and products, facilitating easy recovery of end products [96] while reducing hydrolysis time, decreasing contamination and cost of energy.

Marine fungus Cladosporium sphaerospermum was isolated to extract cellulase enzyme and used to hydrolyze $U$. pertusa biomass, which yielded $112 \mathrm{mg} / \mathrm{g}$ of reducing sugar at $\mathrm{pH} 4$ and temperature $25^{\circ} \mathrm{C}$ for $42 \mathrm{~h}$ [94]. Similarly, marine bacteria was isolated from degrading $U$. lactuca to extract cellulase enzyme, which is tolerant to high salt concentration and alkaline $\mathrm{pH}$ [86]. Polysaccharolytic enzymes extracted from the gut of the abalone Haliotis midae degraded the polysaccharides laminarin, carboxymethylcellulose (CMC), alginate, agarose and carrageenan [109].

\subsubsection{Fermentation of macroalgal sugars}

Macroalgal biomass contain different types of polysaccharides, exclusively composed of glucose i.e., glucans. Main glucans present in green: cellulose and starch; red: cellulose and floridean starch; brown: cellulose and laminarin [46,50,61]. Non-glucans are sulphated polysaccharides such as agar, carrageenan and alginate. In order to obtain higher ethanol, hydrolysis of glucan as well as non-glucan with the fermentation of the resulting sugars is essential [60]. Sugar released from the pretreatment process has been fermented using microorganisms such as yeast, bacteria, and fungi, which ferment these sugars to produce ethanol as a by-product $[41,110]$. Saccharomyces cerevisiae is the commonly used yeast microorganism for fermentation as it readily ferments glucose [111]. However, pretreatment releases mixed sugars namely; glucose, galactose, mannitol, rhamnose and xylose. Due to the lack of xylose transport system, S.cerevisiae is not capable of utilizing xylose [112]. Its uptake takes place through glucose transport system and is regulated by the concentration of glucose. At only low concentration of glucose, xylose is consumed by the yeast [113]. As a result, studies related to isolation of wild yeast strains from various sources is done that can ferment both hexose and pentose sugars yielding higher ethanol. Bacteria, yeast and fungi are explored for xylose fermenting organisms, and mostly preferred organisms are bacteria and yeast as fungi are too slow for competitive industrial process [7].

Single or combination of strains are being attempted for utilization of sugars. Laminaran and mannitol obtained from L. hyperborea were subjected to fermentation using one bacterium (Zymobacter palmae T109) and three yeast strains (Pichia angophorae, Pacchysolen tannophilus and Kluyveromyces marxianus). It was seen that only $P$. angophorae is capable of fermenting laminaran and mannitol at higher oxygen transfer rate to produce $0.43 \mathrm{~g}$ ethanol $/ \mathrm{g}$ substrate [114]. Utilization of mannitol by Zymobacter palmae resulted in the production of $0.37 \mathrm{~g}$ ethanol $/ \mathrm{g}$ mannitol [115], however mannitol was utilized at lower oxygen rate in fermentation media. Mannitol was effectively fermented by E.coli KO11 for production of $0.41 \mathrm{~g}$ ethanol/g mannitol [116]. Similarly, glucuronic acid fermentation was attempted using Pachysolen tannophilus and E.coli.

Bioethanol production from all forms of macroalgal biomass; wet, dried and residues (after extraction of hydrocolloid) was attempted. Residues after extraction of hydrocolloids are rich in cellulose, which have been utilized for bioethanol production. Floating residue of 
Table 4

Bioethanol production from macroalgal biomass.

\begin{tabular}{|c|c|c|c|c|c|c|c|}
\hline $\begin{array}{l}\text { Green } \\
\text { Seaweeds }\end{array}$ & Pretreatment conditions & Enzyme hydrolysis conditions & $\begin{array}{l}\text { Yeast/Bacterial strain and } \\
\text { Fermentation process }\end{array}$ & $\begin{array}{l}\text { Reducing } \\
\text { Sugar g/L }\end{array}$ & $\begin{array}{l}\text { Ethanol } \\
\text { yield } g / g\end{array}$ & $\begin{array}{l}\text { Theoretical } \\
\text { yield (\%) }\end{array}$ & Reference \\
\hline E.intestinalis & $\begin{array}{l}\text { Hydrothermal process }(75 \mathrm{mM} \\
\text { for } 90 \mathrm{~min})\end{array}$ & $\begin{array}{l}\text { Celluclast } 1.5 \mathrm{~L} \text { and Viscozyme } \mathrm{L} \\
\left(55^{\circ} \mathrm{C}, 120 \mathrm{rpm} \text { for } 54 \mathrm{~h}\right)\end{array}$ & $\begin{array}{l}\text { Saccharomyces cerevisiae } \\
\text { KCTC } 1126 \text { (pH } 5.5,30^{\circ} \mathrm{C} \text {, } \\
220 \mathrm{rpm} \text { for } 12 \mathrm{~h})\end{array}$ & 40.4 & 0.21 & 41.74 & {$[120]$} \\
\hline U.fasciata & $\mathrm{H} 2 \mathrm{SO} 4\left(0.1 \%\right.$ at $100^{\circ} \mathrm{C}$ for $\left.1 \mathrm{~h}\right)$ & $\begin{array}{l}\text { Cellulase } 22119 \text { (Sodium acetate } \\
\text { buffer pH } 4.8 \text { at } 45^{\circ} \mathrm{C} \text { for } 36 \mathrm{~h} \text { ) }\end{array}$ & $\begin{array}{l}\text { Saccharomyces cerevisiae } \\
\left(10^{9} \mathrm{CFU} / \mathrm{ml} 28^{\circ} \mathrm{C} \text {, }\right. \\
120 \mathrm{rpm} \text { for } 48 \mathrm{~h})\end{array}$ & 20.6 & 0.45 & 88.24 & [89] \\
\hline U.lactuca & & $\begin{array}{l}\text { Cellulase isolated from } \\
\text { Cladosporium sphaerospermum } \\
\left(\mathrm{pH} 4,25^{\circ} \mathrm{C}, 42 \mathrm{~h}\right)\end{array}$ & $\begin{array}{l}\text { Saccharomyces cerevisiae } \\
\text { MTCC } 180\left(28^{\circ} \mathrm{C} \text { for } 12 \mathrm{~h}\right)\end{array}$ & $112 \mathrm{mg} / \mathrm{g}$ & 0.47 & 92.16 & [94] \\
\hline \multirow[t]{2}{*}{ U.pertusa } & $\begin{array}{l}\text { Citric acid buffer ( } 0.1 \mathrm{M} \\
\text { sterilized using autoclave) }\end{array}$ & $\begin{array}{l}\text { Meicelase (combined } \\
\text { saccharification) } \\
\left(\mathrm{pH} 5.5,50^{\circ} \mathrm{C}, 100 \mathrm{rpm} \text { for }\right. \\
120 \mathrm{~h})\end{array}$ & $\begin{array}{l}\text { Saccharomyces cerevisiae } \\
\text { IAM } 4178\left(30^{\circ} \mathrm{C} \text { for } 36 \mathrm{~h}\right)\end{array}$ & 59.1 & 0.47 & 91.24 & {$[70]$} \\
\hline & $\begin{array}{l}\text { HTLP + Enzyme }\left(150^{\circ} \mathrm{C}, 15\right. \\
\min )\end{array}$ & $\begin{array}{l}\text { Cellulase \& Amyloglucosidase } \\
\text { (pH 4.8, } 50^{\circ} \mathrm{C}, 150 \mathrm{rpm} \text { for } 24 \mathrm{~h} \text { ) }\end{array}$ & $\begin{array}{l}\text { Saccharomyces cerevisiae } \\
\text { ATCC24858 (pH } 5.5, \\
\left.150 \mathrm{rpm}, 30^{\circ} \mathrm{C} \text { for } 24 \mathrm{~h}\right)\end{array}$ & 26 & 0.48 & 93.51 & [97] \\
\hline \multicolumn{8}{|l|}{ Red Seaweeds } \\
\hline G. elegans & & $\begin{array}{l}\text { Meicelase (pH } 5.5 \text { at } 50^{\circ} \mathrm{C} \text { for } \\
120 \mathrm{~h} \text { ) }\end{array}$ & $\begin{array}{l}\text { Saccharomyces cerevisiae } \\
\text { IAM } 4178\left(30^{\circ} \mathrm{C} \text { for } 36 \mathrm{~h}\right)\end{array}$ & 49 & 0.38 & 73.63 & {$[70]$} \\
\hline \multirow[t]{2}{*}{ G. amnasii } & $\mathrm{H}_{2} \mathrm{SO}_{4}(56-168 \mathrm{mM}, 45-240 \mathrm{~min})$ & $\begin{array}{l}\text { Enzyme Viscozyme L ( } 0.024 \\
\text { FBG/ml) }\end{array}$ & $\begin{array}{l}\text { Scheffersomyces stipitis } \\
\left(\mathrm{pH} 5.5,30^{\circ} \mathrm{C}, 200 \mathrm{rpm}\right)\end{array}$ & 43.5 & 0.47 & 92.40 & [108] \\
\hline & $\mathrm{H}_{2} \mathrm{SO}_{4}\left(2 \%, 150^{\circ} \mathrm{C}\right.$ for $\left.4 \mathrm{~h}\right)$ & & $\begin{array}{l}\text { Brettanomyces custersii } \\
\text { KCCM } 11490(\mathrm{pH} 4.8-5.5 \text {, } \\
\left.27-30^{\circ} \mathrm{C}\right)\end{array}$ & 42.2 & 0.38 & 74.51 & [126] \\
\hline \multirow[t]{2}{*}{ G. verrucosa } & $\mathrm{H}_{2} \mathrm{SO}_{4}\left(1.5 \%\right.$, at $80^{\circ} \mathrm{C}$ for $\left.2 \mathrm{~h}\right)$ & & & 87 & 0.43 & 84.29 & {$[60]$} \\
\hline & $373 \mathrm{mM} \mathrm{H}_{2} \mathrm{SO}_{4}$ & $\begin{array}{l}\text { Celluclast } 1.5 \mathrm{~L} \text { and Viscozyme } \mathrm{L} \\
\left(\mathrm{pH} 5,45^{\circ} \mathrm{C}, 150 \mathrm{rpm} \text { for } 72 \mathrm{~h} \text { ) }\right.\end{array}$ & $\begin{array}{l}\text { Saccharomyces cerevisiae } \\
\text { KCTC1126 (pH } 5,30^{\circ} \mathrm{C} \text {, } \\
150 \mathrm{rpm} \text { for } 114 \mathrm{~h})\end{array}$ & 20.4 & 0.48 & 94 & [110] \\
\hline Gracilaria sp. & $\mathrm{H}_{2} \mathrm{SO}_{4}\left(0.1 \mathrm{~N}, 121^{\circ} \mathrm{C}\right.$ for $\left.30 \mathrm{~min}\right)$ & $\begin{array}{l}\text { Commercial enzyme (pH 4.5, } \\
\left.50^{\circ} \mathrm{C}\right)\end{array}$ & $\begin{array}{l}\text { Saccharomyces cerevisiae } \\
\left(30^{\circ} \mathrm{C} \text { for } 48 \mathrm{~h}\right)\end{array}$ & 11.46 & 0.42 & 82.80 & [132] \\
\hline \multirow[t]{4}{*}{ K. alvarezii } & $\begin{array}{l}\text { Soaked in } 1.6 \mathrm{~L} \text { distilled water } \\
\text { for } 30 \mathrm{~min} \text { and boiled at } 90^{\circ} \mathrm{C}\end{array}$ & $\begin{array}{l}\text { Celluloclast } 1.5 \mathrm{~L} \& \text { Novozyme } \\
\left(\mathrm{pH} 5,50^{\circ} \mathrm{C}, 150 \mathrm{rpm} \text { for } 24 \mathrm{~h}\right)\end{array}$ & $\begin{array}{l}\text { Saccharomyces cerevisiae } \\
\left(\mathrm{pH} 5,35^{\circ} \mathrm{C}, 130 \mathrm{rpm} \text { for }\right.\end{array}$ & 79.2 & $\begin{array}{l}0.25 \\
(\mathrm{SHF})\end{array}$ & 49 & [88] \\
\hline & for $1 \mathrm{~h}$ & & $6 \mathrm{~h})$ & & $\begin{array}{l}0.27 \\
(\mathrm{SSF})\end{array}$ & 52.9 & \\
\hline & $\mathrm{H}_{2} \mathrm{SO}_{4}\left(0.2 \mathrm{M}, 130^{\circ} \mathrm{C}\right.$ for $\left.15 \mathrm{~min}\right)$ & & $\begin{array}{l}\text { Commercial brewer's yeast } \\
\left(30^{\circ} \mathrm{C} 120 \mathrm{rpm} \text { pH } 5 \text { for }\right. \\
72 \mathrm{~h})\end{array}$ & 20.4 & 0.21 & 41.18 & [133] \\
\hline & $\begin{array}{l}\mathrm{H}_{2} \mathrm{SO}_{4}\left(0.9 \mathrm{~N}, 100^{\circ} \mathrm{C} \text { for } 1 \mathrm{~h}\right) \\
5 \text { cycles }\end{array}$ & & $\begin{array}{l}\text { Saccharomyces cerevisiae } \\
\text { NCIM }\left(5 \% \mathrm{v} / \mathrm{v}, 30^{\circ} \mathrm{C}\right. \\
150 \mathrm{rpm}, \mathrm{pH} 6.4-6.8 \text { for } \\
48 \mathrm{~h})\end{array}$ & 51.9 & 0.42 & 82.36 & [117] \\
\hline $\begin{array}{l}\text { P. palmata } \\
\text { Brown Seaweeds }\end{array}$ & Acid hydrolysis & & & 21.84 & 0.173 & 33.92 & [133] \\
\hline A. crassifolia & $\begin{array}{l}\text { Citric acid buffer ( } 0.1 \mathrm{M} \\
\text { sterilized using autoclave) }\end{array}$ & $\begin{array}{l}\text { Meicelase }\left(5 \mathrm{~g} / 1 \text { at } 50^{\circ} \mathrm{C} \text { for }\right. \\
120 \mathrm{~h})\end{array}$ & $\begin{array}{l}\text { Saccharomyces cerevisiae } \\
\text { IAM } 4178\left(30^{\circ} \mathrm{C} \text { for } 36 \mathrm{~h}\right)\end{array}$ & 66.3 & 0.38 & 75 & [70] \\
\hline \multirow[t]{2}{*}{ L. hyperborea } & Extracted in water at $65^{\circ} \mathrm{C}$ & & Pichia angophorae & 30 & 0.43 & 84.31 & [114] \\
\hline & $\begin{array}{l}\text { Extracted in water } 121^{\circ} \mathrm{C} \text { for } \\
20 \mathrm{~min}\end{array}$ & & $\begin{array}{l}\text { Zymobacter palmae }(\mathrm{pH} 6 \text {, } \\
\left.30^{\circ} \mathrm{C}\right)\end{array}$ & $\begin{array}{l}3.8 \\
\text { (mannitol) }\end{array}$ & 0.38 & 74.51 & [115] \\
\hline S. sagamianum & & & $\begin{array}{l}\text { Pichia stipitis (pH } 5 \text {, } \\
200 \mathrm{rpm} \text { ) }\end{array}$ & 19.8 & 0.35 & 69.32 & [125] \\
\hline \multirow[t]{4}{*}{ S. janponica } & $\begin{array}{l}\mathrm{H}_{2} \mathrm{SO}_{4}\left(1 \mathrm{mM}, 121^{\circ} \mathrm{C} \text {, for }\right. \\
120 \mathrm{~min})\end{array}$ & $\begin{array}{l}\text { Cellulase and cellobiase ( } \mathrm{pH} 4.8 \\
\left.50^{\circ} \mathrm{C}, 150 \mathrm{rpm} \text { for } 48 \mathrm{~h}\right)\end{array}$ & $\begin{array}{l}\text { Saccharomyces cerevisiae } \\
\left(\mathrm{pH} 6.5,30^{\circ} \mathrm{C} \text { for } 36 \mathrm{~h}\right)\end{array}$ & 34 & 0.41 & 80.74 & [103] \\
\hline & $\begin{array}{l}\text { Acid hydrolysis }\left(0.1 \mathrm{~N}, 121^{\circ} \mathrm{C}\right. \\
\text { for } 15 \mathrm{~min})\end{array}$ & $\begin{array}{l}\text { Celluclast } 1.5 \mathrm{~L} \text {, Viscozyme L, } \\
\text { Novoprime } 959 \text {, Novoprime } 969 \\
\text { or AMG } 300 \mathrm{~L}\left(50^{\circ} \mathrm{C}, 150 \mathrm{rpm} \text { for }\right. \\
24 \mathrm{~h})\end{array}$ & E.coli KO11 $\left(30^{\circ} \mathrm{C}\right.$ for $\left.24 \mathrm{~h}\right)$ & 30.54 & 0.41 & 80.39 & [116] \\
\hline & $\begin{array}{l}\mathrm{H}_{2} \mathrm{SO}_{4}\left(40 \mathrm{mM}, 121^{\circ} \mathrm{C} \text { for }\right. \\
60 \mathrm{~min})\end{array}$ & Novozyme (Termamyl 120L) & $\begin{array}{l}\text { Pichia angophorae KCTC } \\
17574\left(5 \% 30^{\circ} \mathrm{C} \text { at }\right. \\
200 \mathrm{rpm}, 136 \mathrm{~h})\end{array}$ & 45.6 & 0.16 & 33.3 & {$[52]$} \\
\hline & $\begin{array}{l}\text { Shredding and enzymatic }\left(23^{\circ} \mathrm{C}\right. \\
\text { for } 30 \mathrm{~min})\end{array}$ & & Ethanol Red yeast $\left(32^{\circ} \mathrm{C}\right)$ & 35 & 0.45 & 88.24 & [126] \\
\hline U. pinnatifida & $\begin{array}{l}\text { Dilute acid }\left(5 \% \mathrm{H} 2 \mathrm{SO} 4,120^{\circ} \mathrm{C}\right. \\
\text { for } 24 \mathrm{~h})\end{array}$ & $\begin{array}{l}\text { Celluloclast } 1.5 \mathrm{~L} \& \\
\text { Novozyme188 }\left(\mathrm{pH} 4.6,45^{\circ} \mathrm{C}\right)\end{array}$ & $\begin{array}{l}\text { E.coli (pH } 7170 \mathrm{rpm}, 37^{\circ} \mathrm{C} \\
\text { for } 12 \mathrm{~h} \text { ) }\end{array}$ & 20 & 0.144 & 28.2 & [107] \\
\hline
\end{tabular}

L. japonica was subjected to acid pretreatment followed by enzyme hydrolysis, an ethanol yield of $14 \mathrm{~g} / \mathrm{L}$ was obtained from $34 \mathrm{~g} / \mathrm{L}$ of reducing sugar achieving $41.2 \%$ conversion efficiency [103]. Similarly, $K$. alvarezii dried residues after extraction of sap were utilized for production of bioethanol [117]. Wet biomass of G. amansii was used as bioethanol feedstock, Brettanomyces custersii KCTC 18154P strain was utilized for fermentation of the hydrolysate due to the ability of the strain in exhibiting co-fermentability. Utilization of raw or wet macroalgal biomass is not feasible for bioethanol production due to high viscosity of the medium for fermentation [118]. In green seaweeds, studies have focused on conversion of cellulose and starch to bioethanol. Whereas conversion of other sulphated polysaccharides such as Ulvan to produce ethanol is yet to be explored [60]. Non availability of natural strains capable of fermenting alginate, a major polysaccharide of brown algae [60], makes it difficult to achieve higher ethanol production.

Fermentation is carried out in two process, Separate Hydrolysis and 
Fermentation (SHF) and Simultaneous Saccharification and Fermentation (SSF) [119]. SHF involves hydrolysis and fermentation performed sequentially, whereas SSF involves performing simultaneous hydrolysis and fermentation [74]. Saccharina japonica, Undaria pinnatifida and Poryphyra were subjected to SSF using Pichia angophorae KCTC strain and obtained $7.7 \mathrm{~g} / \mathrm{L}$ of ethanol [52]. SHF process is faster but presence of inhibitors resulting from acid pretreatment has significant impact on yeast microorganisms. SSF is preferred over SHF as the sugars released are readily metabolized by yeast microorganisms, which results in a faster ethanol production rate and lower capital costs. SSF has a drawback due to the difference in temperature optima of cellulase $\left(50^{\circ} \mathrm{C}\right)$ and fermenting microorganism $\left(35^{\circ} \mathrm{C}\right)$. SHF and SSF of Enteromorpha intestinalis or Ulva (Enteromorpha) intestinalis produced $8.6 \mathrm{~g} / \mathrm{L}$ and $7.6 \mathrm{~g} / \mathrm{L}$ with $30.5 \%$ and $29.6 \%$ fermentation efficiency respectively. Conversion of ethanol to acetic acid by yeast and suboptimal temperature of $30^{\circ} \mathrm{C}$ than the optimum temperature of $55^{\circ} \mathrm{C}$ for enzyme activity was attributed to the lower ethanol yield in SSF [120].

Higher temperature shortens the exponential phase of the yeast cell [121] affecting the ethanol production. However, this has been overcome through thermotolerant yeast strains or cell immobilization technique which allows higher processing temperatures [120-123]. Thermotolerant yeast species such as Candida tropicalis and Kluyveromyces marxianus $\left(38-45^{\circ} \mathrm{C}\right.$ ) are mainly utilized to produce bioethanol from lignocellulosic biomass [123,124].

Bioethanol production from macroalgae utilized commercial yeast strains such as S. cerevisiae KCTC 1126 [110,111], MTCC 180 [60], IAM 4178 [70], ATCC 24858 [97], KCTC 17574 [52], Pichia stipitis [125], Pichia angophorae [114], Scheffersomyces stipitis [108], Brettanomyces custersii KCCM 11490 [126], Ethanol red yeast [36] and bacterial strains such as Zymobacter palmae [115] and Escherichia coli SJL2526 [107]. Fermentation of macroalgal polysaccharides is carried out at $\mathrm{pH} 4.5-6.8$ and temperature $25-30^{\circ} \mathrm{C}$ and the incubation time is largely strain dependent. The yeast growth rate is dependent on temperature and fermentation time [131]. However, exponential phase of yeasts are shortened at large temperatures and $\mathrm{pH}<4$, requiring longer incubation for higher ethanol production, as reported in S.cerevisiae BY4742 [64]. Shorter fermentation time causes inadequate growth of microorganisms resulting in inefficient fermentation [132].

In order to optimize ethanol yield and improve substrate utilization range [129], studies focused on immobilization of yeast cells [121-130]. Immobilized yeast cells have enhanced the ethanol productivity and reusable for 15 cycles with bacterial cellulose-alginate sponge [121]. Free and immobilized strains were used for molasses fermentation. Free cells were unable to ferment at temperatures greater than $38^{\circ} \mathrm{C}$, compared to immobilized yeast. Immobilized yeast strains exhibited both psychrophilic and thermo-tolerant characteristics, suitable for fermentation in a wide range of temperatures [131] and increased ethanol yield and higher cellular stability, while reducing downstream processing expenses [132]. Fermentation of U.lactuca biomass done using immobilized Saccharomyces cerevisiae strain, yielded ethanol (concentration of $12 \mathrm{~g} / \mathrm{g}$ of sugar) with conversion efficiency of $47.1 \%$ [130]. Table 4 summarizes ethanol yield from the three types of macroalgae along with the process conditions and strains utilized for hydrolysis (pretreatment) and fermentation. Fermentation of red seaweed Gracilaria using free yeast cells yielded $0.41 \mathrm{~g} / \mathrm{g}$ of ethanol and immobilized yeast cells yielded $0.42 \mathrm{~g} / \mathrm{g}$ achieving 80 and $82.8 \%$ fermentation efficiency [132].

Studies emphasize on production of bioethanol from readily available carbohydrates of brown and red seaweeds, but utilization of red and brown seaweeds such as Kappaphycus, Gelidium, Gracilaria, Sargassum, and Laminaria have the likelihood to override the existing multi-billion dollar hydrocolloid industry [89]. This can be addressed in two ways: (i) utilization of cellulosic rich residue after hydrocolloid extraction, (ii) exploration of green seaweeds which are abundantly recorded from various estuaries and abandoned aquaculture ponds across maritime states in India [134]. Green seaweeds exhibit characteristics of a potential feedstock for biofuel production by their cosmopolitan distribution, wide environmental tolerance, higher growth rates and year around productivity [135]. In India, seaweeds are seldom consumed as a food source, and the suitability for biofuel production is still underexplored as several species accumulate different levels of carbohydrate. Seaweeds contain low amounts of polysaccharides composed of glucose, highlighting the need for ethanol production from carbohydrates including sulphated polysaccharides, sugar acids and sugar alcohols. Not all the reported microorganisms are capable of fermenting these sugars and a major limitation is lack of tractable microorganisms that can efficiently ferment all sugars extracted from seaweed into ethanol. Isolation of yeast strains to ferment both pentose (C5) and hexose (C6) sugars are vital for achieving high ethanol yield. In this backdrop, the current study explores bioethanol prospects from viable feedstock habituated in the west coast of India, which involves:

(i) screening and prioritizing potential macroalgal feedstock for bioethanol production based on the biochemical composition;

(ii) comparative performance analysis of chemical and biological pretreatment method for extraction of sugar from macroalgal biomass; and

(iii) bioethanol potential assessment of green seaweeds and comparative analysis of ethanol yield across macroalgal species.

\section{Materials and methods}

\subsection{Macroalgal resource assessment and screening of potential feedstock for biofuel production}

Macroalgal sampling has been done monthly during low tide period. Due to the immersion and emersion periods in rocky shore, a $0.25 \mathrm{~m}^{2}$ random quadrats sampling was carried out. Algal biomass within the quadrat were handpicked, species-wise sorted and washed in seawater to remove adhering epiphytes. Collected samples were identified using standard identification keys $[61,136]$ and standing biomass was determined, which is expressed in $\mathrm{g} / \mathrm{m}^{2}$. In areas, where seaweeds were not accessible, only qualitative data such as the presence of seaweed species were recorded with location details using high spatial resolution virtual remote sensing data (Google Earth).

\subsection{Biochemical composition along Central West Coast of India}

Species samples were washed thoroughly in seawater, followed by tap water to clean debris of extraneous material. Cleaned seaweeds were sun dried in the shade for 2-3 days, followed by drying in the hot air oven, below $60^{\circ} \mathrm{C}$ till constant weight is attained. The dried material was pulverized and sieved to obtain a uniform particle size. The powder was preserved in a zip lock pouches for subsequent analysis of total carbohydrate [137], cellulose [138], protein [139], and lipid [140] contents. Carbon, hydrogen and nitrogen were estimated using CHN elemental analyser. These samples were analyzed in triplicates and the mean values were considered for further calculations and results are expressed in mean $\pm S D$.

\subsection{Macroalgal pretreatment process}

Sugar from macroalgae was extracted using boiling water, sonication, dilute acid and alkali pretreatment. Seaweed was boiled in a $10 \mathrm{ml}$ water for $30 \mathrm{~min}$, sonication was carried out using an ultrasonic bath (frequency $35 \mathrm{kHz}$ ) for $30 \mathrm{~min}$. Dilute acid pretreatment involved $0.7 \mathrm{~N} \mathrm{H}_{2} \mathrm{SO}_{4}$ and alkali pretreatment was carried out using $5 \mathrm{~N} \mathrm{NaOH}$ for $30 \mathrm{~min}$. Neutralization was carried out for U.lactuca and E.intestinalis acid hydrolysate using $\mathrm{Na}_{2} \mathrm{CO}_{3}, \mathrm{NaOH}$, Activated charcoal and $\mathrm{Ca}(\mathrm{OH})_{2}$. The sugar removal (\%) by these agents was calculated as per equation (Eq. (1)). 
$\%$ Sugar removal $=\frac{(A-B)}{A} X 100$

where, A is the amount of reducing sugar $(\mathrm{mg} / \mathrm{g}$ ) before treatment, and B is the amount of reducing sugar $(\mathrm{mg} / \mathrm{g})$ after treatment [141].

\subsection{Enzyme hydrolysis}

Enzyme was isolated from marine bacteria Vibrio parahaemolyticus [90] and hydrolysis was carried out for direct biomass and acid pretreated biomass for U.lactuca and E.intestinalis to demonstrate the effect of acid pretreatment in enzyme hydrolysis. Enzyme hydrolysis was carried out at $55^{\circ} \mathrm{C}$ up to $48 \mathrm{~h}$ and reducing sugar was estimated every $6 \mathrm{~h}$.

\subsection{Bioethanol production from selected macroalgae}

Dried biomass ( $5 \% \mathrm{w} / \mathrm{v}$ ) was pretreated using dilute $(0.7 \mathrm{~N}) \mathrm{H}_{2} \mathrm{SO}_{4}$ to release sugars and estimated for reducing sugars by 3,5 dinitrosalicylic acid method [142]. Acid hydrolysate neutralized using $\mathrm{Na}_{2} \mathrm{CO}_{3}$. Released fermentable sugars were subjected to fermentation using cashew yeast (CY) and toddy yeast (TY) at $30^{\circ} \mathrm{C}$ for $18 \mathrm{~h}$ in Separate hydrolysis and fermentation (SHF). Saccharification and Fermentation (SSF) was carried out using $2 \%(\mathrm{w} / \mathrm{v})$ pretreated biomass and $6 \%(\mathrm{v} / \mathrm{v})$ enzyme and yeast were added to the medium and fermented using $\mathrm{CY}$ and TY at $55^{\circ} \mathrm{C}$ for $18 \mathrm{~h}$. Co-fermentation of algal hydrolysate was also carried out for SHF and SSF. Ethanol was estimated using GC-FID. Bioethanol production from all the macroalgal biomass was estimated based on published literatures and the probable relationship of ethanol yield and multivariate is determined through regression analyses.

\section{Results and discussions}

\subsection{Scope for bioethanol production from macroalgal biomass}

The availability of spectrum of species amenable for biofuel production is one of the unique aspect of algae when compared to other advanced feedstock [35]. Production of different types of biofuels (bioethanol, diesel, bio-oil, and bio-hydrogen) is optimized by prioritizing species.

Characteristics of prioritized macroalgal feedstock for sustainable biofuel production are (i) availability throughout the year (during all seasons) and (ii) presence of higher quantum of sugar.

\subsubsection{Macroalgal feedstock availability and selection}

Indian coast has about 1153 marine algal species belonging to 271 genera, of which 60 species are commercially important. Rocky beaches, mudflats, estuaries, coral reefs and lagoons are the preferred habitats for macroalgae. Indian coast harbors predominantly intertidal and subtidal algal communities [143]. Macroalgal feedstock (for bioethanol production) distribution along the Indian Coast and islands were compiled from various secondary data sources [144-150] along with the locations based on the current field investigations is represented in Fig. 4. Seaweed species belonging to Laminaria genera (Brown algae or Phaeophyta) are not recorded in India and these are algae of cold waters and certain brown algae of orders Dictyotales and Fucales (e.g. Sargassum) are distinctly warm-water plants [151] are abundantly spread and are recorded from Indian Coast. Kappaphycus alvarezii, a red algae is native of Indonesia and Philippines and introduced in India for commercial cultivation purpose [152], which has now colonized in various parts of Gulf of Mannar.

Setting up of bio refinery necessitates easier cultivation strategies apart from ensuring the availability of feedstock during all seasons. During the current field investigations covering 24 months, 25 seaweed species belonging to 19 genera were recorded from intertidal zone.
Ulva

Gelidium

Gracilaria

Sargassum

Kappaphycus (Introduced species)

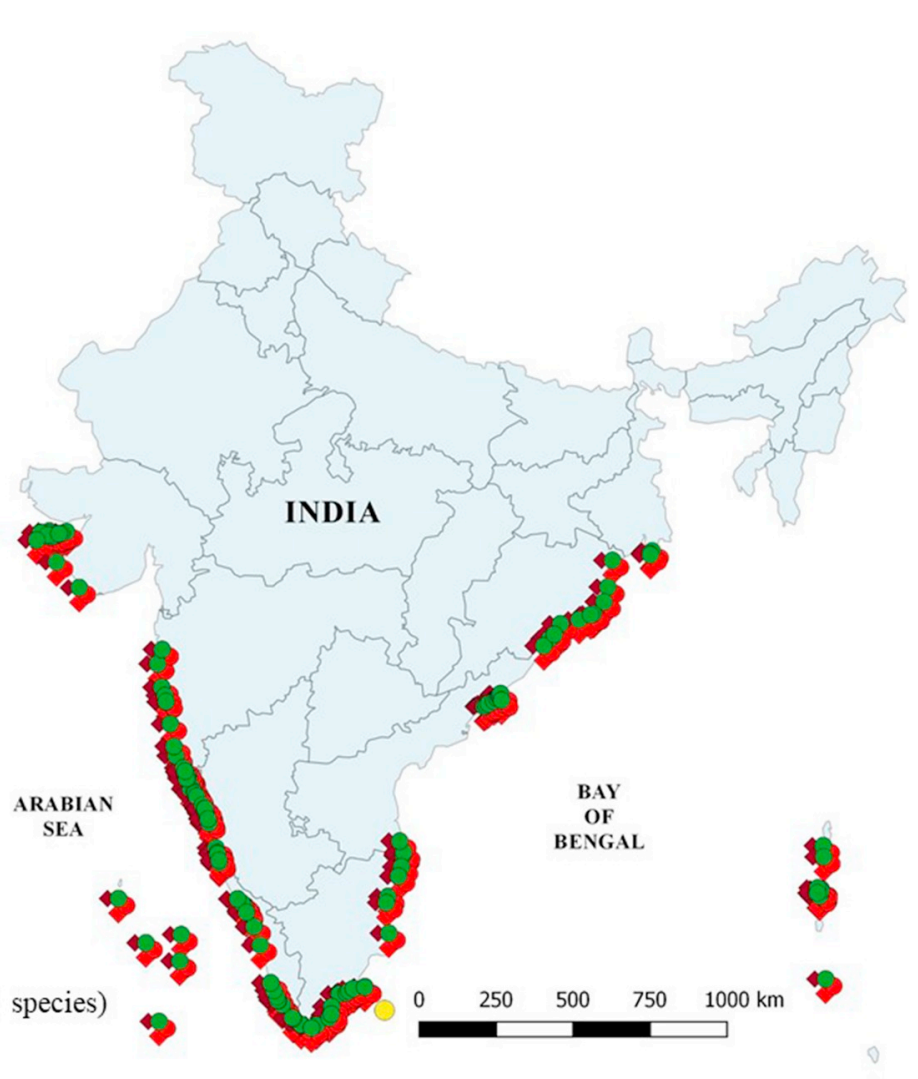

Fig. 4. Distribution of potential macroalgal feedstock of Indian coast. 
Among these, eight seaweed species abundantly grows during postmonsoon season in the Central West Coast. These species include Enteromorpha intestinalis $\left(938.5 \mathrm{~g} / \mathrm{m}^{2}\right)$, Ulva lactuca $\left(1024.5 \mathrm{~g} / \mathrm{m}^{2}\right)$, Chaetomorpha media $\left(441.8 \mathrm{~g} / \mathrm{m}^{2}\right)$, Gracilaria corticata $\left(1039.5 \mathrm{~g} / \mathrm{m}^{2}\right)$, Gelidium pusillum $\left(205.4 \mathrm{~g} / \mathrm{m}^{2}\right)$, Grateloupia lithophila $\left(196.6 \mathrm{~g} / \mathrm{m}^{2}\right)$, Sargassum ilcifolium $\left(1175.7 \mathrm{~g} / \mathrm{m}^{2}\right)$ and Padina tetrastromatica $(1506.7 \mathrm{~g} /$ $\mathrm{m}^{2}$ ), which were considered for further analysis of biochemical composition (Fig. 5). It was seen that green seaweeds; U.lactuca and $E$. intestinalis, and red seaweed G.corticata occurred in sufficient quantity during all seasons. Occurrence of Ulva and Enteromorpha in all the seasons is attributed to their euryhaline nature, whereas G.corticata species are strictly marine and are restricted to open ocean environment [153]. Year round optimal biomass production of these macroalgal species, overcomes the seasonal constraints faced by the first and second generation biofuel feedstock [45].

\subsubsection{Biochemical composition of selected seaweeds}

Macroalgal species with the higher quantum of sugar plays an important role as the composition of sugar influences the ethanol yield. Biochemical composition of chosen macroalgae were carried out focusing mainly on higher carbohydrate content which is an essential parameter for prioritizing feedstock for bioethanol production (Table 5). Algal biomass are composed of large quantities of carbohydrates in the cell wall mostly in the form of structural (cellulose) and storage (starch) polysaccharides, that serve as substrate for fermentation. Highest total carbohydrate was recorded from green seaweed Ulva lactuca $(62.15 \pm 12.8 \%)$ followed by G. lithophila $(60.5 \pm 11.4 \%)$, G.pusilum $(50.1 \pm 3.4 \%)$ and E.intestinalis $(40.1 \pm 14.6 \%)$. Among these, G.lithophila and G.pusilum have lower biomass production as compared to Ulva and Enteromorpha, which makes them unsuitable as feedstock for biofuel production. Protein ranged from $3.7 \pm 0.94$ to $27.3 \pm 15.21 \%$. Highest protein content was recorded from C. media $(27.3 \pm 15.21 \%)$ followed by $E$. intestinalis $(20.4 \pm 0.67 \%)$ and $U$. lactuca $(17.3 \pm 1.68 \%)$. In green seaweed Ulva, protein concentration ranged from 9 to $33 \%$. Lowest protein recorded was from $G$. lithophila $(3.7 \pm 0.94 \%)$. In general, protein fraction is lower in brown seaweeds (3-15\% DW) compared to green or red seaweeds $(10-47 \% \mathrm{DW})$ similar to the earlier report [154]. Lipid ranged from $0.5 \pm 0.2$ to $6 \pm 4.4 \%$. Highest lipid was estimated in $U$. lactuca $(6 \pm 4.4 \%)$ followed by G. pusillum $(3.7 \pm 1.4 \%)$, $P$. tetrastromatica $(2.8 \pm 0.3 \%)$. Lowest lipid content estimated in G. corticata $(0.5 \pm 0.2 \%)$. Transesterification of lipids extracted from Enteromorpha biomass yielded $90.6 \%$ biodiesel [135], which highlights that Enteromorpha as a promising feedstock for biodiesel production.

Elemental analysis of the seaweeds indicates $25.31-37.95 \%$ of carbon, $4.52-6.48 \%$ hydrogen and $1.88-4.36 \%$ Nitrogen. Highest carbon, hydrogen and nitrogen content were recorded respectively from $G$. pusillum (C: $37.95 \%$ ), G.pusillum (H: 6.48\%) and E.intestinalis (N: 4.36\%) respectively. Higher cellulose content was estimated in U.lactuca $(14.03 \pm 0.14 \%)$, followed by E.intestinalis $(12.10 \pm 0.53 \%)$ and C.media $(10.53 \pm 0.17 \%)$ least cellulose content was estimated in $G$. corticata $(0.87 \pm 0.07 \%)$. Cellulose is a glucan present in green seaweeds, which can be easily hydrolysed by using enzyme and subsequently fermented to produce bioethanol. Green seaweeds are rich in cellulose content $(>10 \%)[37,89,105]$ when compared to red and brown seaweed (2-10\%).

\subsubsection{Reducing sugar extraction using pretreatment methods}

Chosen seaweeds composed of all the three types of algae (green, red and brown) with varied amounts of sugar and the complexity of the seaweed is reflected between structural and carbohydrate components $[105,155,156]$. It is therefore important to carefully choose the pretreatment process based on the biomass and an appropriate efficient pretreatment process to achieve a high yield of sugar for low energy input. The reducing sugar was determined using various pretreatment method as shown in Fig. 5. Pretreatment using boiling water yielded very low reducing sugar and it was observed that red and brown algae formed gel during this pretreatment process due to the presence of sugars like Agar, Carrageenan and Alginate which possess hydrocolloid properties $[70,157,158]$. It is seen that, liquid hot water pretreatment releases most of oligosaccharides [159]. U. lactuca biomass was subjected to four different pretreatments namely; ethanol organ solvent, alkaline, liquid hot water and ionic liquid treatments. Organo solvent and liquid hot water treatment produced highest glucan recovery of $80.8 \mathrm{~g} / 100 \mathrm{~g} \mathrm{DW}$ and $62.9 \mathrm{~g} / 100 \mathrm{~g}$ DW respectively [160]. Sonication pretreatment also yielded lower reducing sugar, since sonication is most commonly used in extraction of lipid from microalgae [161], highest fatty acid composition of C16:0 and C18:1 was achieved in Spirogyra sp. employing sonication as cell disruptions technique [40]. Higher reducing sugar was extracted from all types of seaweeds during the dilute acid pretreatment. Dilute acid reduces the degree of polymerization resulting in recovery of $80-90 \%$ of hemicellulose exposing cellulosic fraction accessible to enzyme digestion [162]. Pre-treated Palmaria palmata, a red alga was exposed to acid hydrolysis, generated $218 \mathrm{mg} / \mathrm{g}$ of reducing sugar [133] and Grateloupia lithophila gave $191 \mathrm{mg} / \mathrm{g}$ of reducing sugar in the current study. Hence, it is feasible to obtain fermentable sugars with lower inhibitor concentration using extremely lower acid concentration [163]. Benefits of treating biomass with extremely low acid concentration simplifies downstream process such as neutralization and waste treatment. Reducing sugar of $14.7 \mathrm{~g} / \mathrm{L}$ was obtained from E.intestinalis by dilute acid concentration of

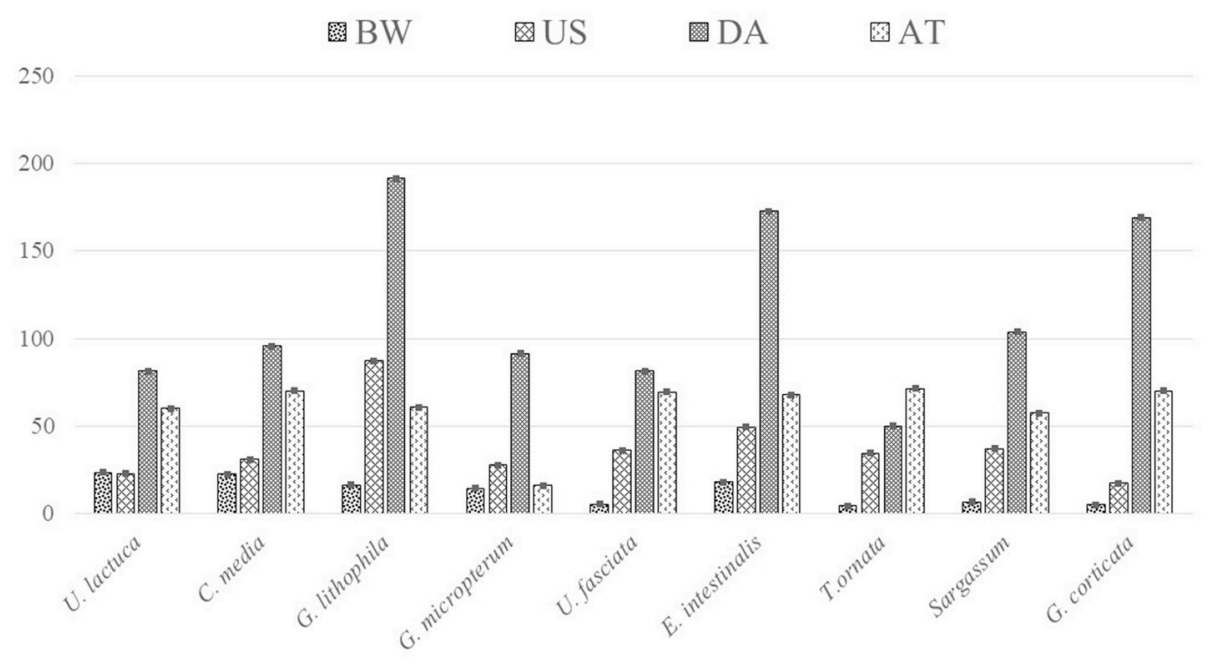

Fig. 5. Reducing sugar $\left(\mathrm{mgg}^{-1}\right)$ extracted using various pretreatment methods for selected seaweeds. 
Table 5

Biochemical composition (\%) of seaweeds along Central West Coast of India.

\begin{tabular}{|c|c|c|c|c|c|c|c|c|c|}
\hline Seaweeds & Total carbohydrate & Soluble carbohydrate & Insoluble carbohydrate & Protein & Lipid & Cellulose & C & $\mathrm{H}$ & $\mathrm{N}$ \\
\hline U.lactuca & $62.15 \pm 12.8$ & $5.5 \pm 0.07$ & $56.5 \pm 12.7$ & $17.3 \pm 1.68$ & $6 \pm 4.4$ & $14.03 \pm 0.14$ & 25.31 & 5.44 & 2.61 \\
\hline E.intestinalis & $40.1 \pm 14.6$ & $7.5 \pm 0.02$ & $32.5 \pm 14.5$ & $20.4 \pm 0.67$ & $2.8 \pm 0.1$ & $12.10 \pm 0.53$ & 33.00 & 6.44 & 4.36 \\
\hline C.media & $25.5 \pm 11.2$ & $5.3 \pm 0.02$ & $20.1 \pm 11$ & $27.3 \pm 15.21$ & $0.6 \pm 0.01$ & $10.53 \pm 0.17$ & 30.14 & 5.31 & 3.28 \\
\hline G.corticata & $28.2 \pm 11.1$ & $13.4 \pm 0.01$ & $14.7 \pm 11$ & $14.4 \pm 1.33$ & $0.5 \pm 0.2$ & $0.87 \pm 0.07$ & 26.46 & 5.01 & 1.89 \\
\hline G. pusillum & $50.1 \pm 3.4$ & $4.7 \pm 0.01$ & $45.4 \pm 3.4$ & $8 \pm 2.04$ & $3.7 \pm 1.4$ & $1.55 \pm 0.05$ & 37.95 & 6.48 & 3.45 \\
\hline G. lithophila & $60.5 \pm 11.4$ & $14.8 \pm 0.01$ & $45.7 \pm 11$ & $3.7 \pm 0.94$ & $2.4 \pm 1.3$ & $6.23 \pm 0.16$ & 29.60 & 6.15 & 2.52 \\
\hline S. ilcifolium & $26.4 \pm 13.4$ & $3.6 \pm 0.01$ & $22.7 \pm 13$ & $12.4 \pm 0.67$ & $1.9 \pm 0.01$ & $1.30 \pm 0.09$ & 26.20 & 4.52 & 1.88 \\
\hline P.tetrastromatica & $32.5 \pm 13.23$ & $3.5 \pm 0.02$ & $28.9 \pm 13.2$ & $9.7 \pm 1.76$ & $2.8 \pm 0.3$ & $1.48 \pm 0.07$ & 30.68 & 5.54 & 2.35 \\
\hline
\end{tabular}

$75 \mathrm{mM} \mathrm{H}_{2} \mathrm{SO}_{4}$ [120]. Sequential acid hydrolysis was carried out to concentrate the sugar: hydrolysate of first cycle was utilized as hydrolyzing liquid for the 2nd cycle and up to 5th cycle [117] and generated $72 \mathrm{~g} / \mathrm{L}$ of reducing sugar at the end of 5 th cycle during $0.9 \mathrm{~N} \mathrm{H}_{2} \mathrm{SO}_{4}$ hydrolysis from the seaweed granules. However, loss of liquid volume encountered in the hydrolysate that is attributed to the sorption loss by residue. Pulverized wet biomass of Gelidium amansii, red seaweed was subjected to continuous acid hydrolysis which yielded higher galactose and lower inhibitor concentration than batch reactor [126].

Utilization of red and brown seaweeds biomass for bioethanol production can lead to debate on hydrocolloid versus fuel affecting the existing multibillion hydrocolloid industry [89]. Therefore, for further processes of detoxification, enzyme hydrolysis and fermentation, two seaweeds Ulva lactuca and Enteromorpha intestinalis were selected as both the species satisfy the criteria of potential feedstock for bioethanol production such as; annual availability, carbohydrate rich biomass, producing higher reducing sugar concentration, ease of harvest by mechanical means, amenable to transplanting and reproducing prolifically in given environment [89].

3.1.3.1. Detoxification of acid hydrolysate. Detoxification of inhibitors (HMF and LA) resulting from acid hydrolysis was carried out using activated charcoal [164], which removed 38.8\% LA and 70.37\% HMF. However activated charcoal also removed sugars $14.5 \%$ glucose and $20.3 \%$ galactose present in the hydrolysate [141]. In the current study, highest sugar removal of $63.5 \%$ and $52 \%$ was recorded from activated charcoal for U.lactuca and E.intestinalis acid hydrolysate respectively. Similarly, $\mathrm{Ca}(\mathrm{OH})_{2}$ was used for neutralizing the hydrolysate, which led to gypsum (calcium sulphate) formation, which was removed through filtration [117] also calcium ions catalyzes alkaline degradation of mono-saccharides in the over liming process, resulting in removal of fermentable sugars [141]. Similar results were observed in the current study, where $\mathrm{Ca}(\mathrm{OH})_{2}$ treatment removed sugar from U.lactuca $(56.1 \%)$ and E.intestinalis (23.3\%) acid hydrolysate. Least effect of sugar removal was recorded in $\mathrm{Na}_{2} \mathrm{CO}_{3}$ neutralization process (Table 6) U.lactuca (39.8\%) and E.intestinalis (14.7\%).

\subsection{Enzyme hydrolysis}

Enzyme hydrolysis of U.lactuca and E.intestinalis yielded lower reducing sugar, compared to pretreated biomass during the incubation period. In order to overcome recalcitrance in second generation feedstock, the biomass was pretreated prior to enzyme hydrolysis. The pretreatment removed the lignin and hemicellulose exposing the cellulose fibers for enzyme hydrolysis [64,66,99,165]. Pretreated biomass is then subjected to enzyme hydrolysis, where cellulase enzymes bind to cellulose and disintegrate it into simple sugars (glucose). Algal biomass in the current study was pretreated using dilute acid and then subjected to enzyme hydrolysis (Fig. 6a and b). Pre-treatment breaks down the crystalline cellulose structure, the major constituents in the biomass cell walls and maximize enzymatic conversion to reducing sugars [53,105, 155,166]. Despite longer incubation period for sugar release, enzyme hydrolysis is widely preferred due to the absence of any inhibitors formation [70].

\subsection{Bioethanol production from selected macroalgae}

Production of bioethanol from carbohydrate rich biomass is economical and sustainable. However, investigations are focused on improving the yield of bioethanol from seaweeds using appropriate microorganisms that have capabilities to convert all sugars present in the seaweeds and achieve ethanol yield of $0.47 \mathrm{~g} / \mathrm{g}$ reducing sugar [89, $167,168]$. SHF and SSF process was carried out for E.intestinalis and $U$. lactuca feedstock.

\subsubsection{SHF and SSF}

Macroalgal feedstock E.intestinalis (EI) and U.lactuca (UL) were pretreated using $0.7 \mathrm{~N}$ and $0.5 \mathrm{~N} \mathrm{H}_{2} \mathrm{SO}_{4}$ respectively. Seaweed hydrolysate was neutralized and then subjected to fermentation using $\mathrm{CY}$ and TY strain and conversion efficiency calculated assuming the sugar available in the hydrolysate are fermentable (Table 7). Higher ethanol yield of $1.63 \mathrm{~g}$ and $25.8 \%$ efficiency was recorded for EITY combination, whereas ULCY produced lower ethanol yield of $0.37 \mathrm{~g}$ achieving $12.1 \%$ efficiency. Co-fermentation of E.intestinalis hydrolysate yielded $0.8 \mathrm{~g}$ with $21.7 \%$ efficiency, whereas U.lactuca yielded $0.63 \mathrm{~g} / \mathrm{g}$ achieving $20.4 \%$ efficiency [120]. Pretreated E.intestinalis to $75 \mathrm{mM} \mathrm{H}_{2} \mathrm{SO}_{4}$ and subjected to SHF and obtained ethanol of $8.6 \mathrm{~g} / \mathrm{L}(0.86 \mathrm{~g})$ achieving $30.5 \%$ efficiency at $48 \mathrm{~h}$. At the end of fermentation $10 \mathrm{~g} / \mathrm{L}$ of reducing sugar remained unutilized indicating presence of non-fermentable sugar not consumed by the yeast S.cerevisiae. U.fasciata enzyme hydrolysate was subjected to fermentation and $1.28 \mathrm{~g}$ of ethanol yield was produced achieving $88.27 \%$ efficiency indicating higher reducing sugar conversion efficiency and ethanol yield than those reported for red and brown seaweeds [169].

SSF of E.intestinalis produced $7.6 \mathrm{~g} / \mathrm{L}$ with $26.9 \%$ efficiency, lower yield was attributed to the suboptimal temperature of $32{ }^{\circ} \mathrm{C}$ which is unsuitable for enzyme hydrolysis [120]. In this study, SSF process (Table 8) produced higher efficiency when compared to SHF. The

Table 6

Comparison of reducing sugar removal after neutralization process.

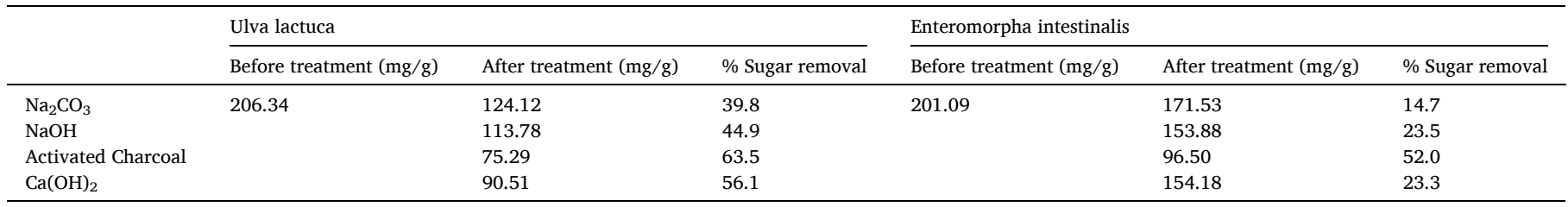




\section{Enteromorpha intestinalis}
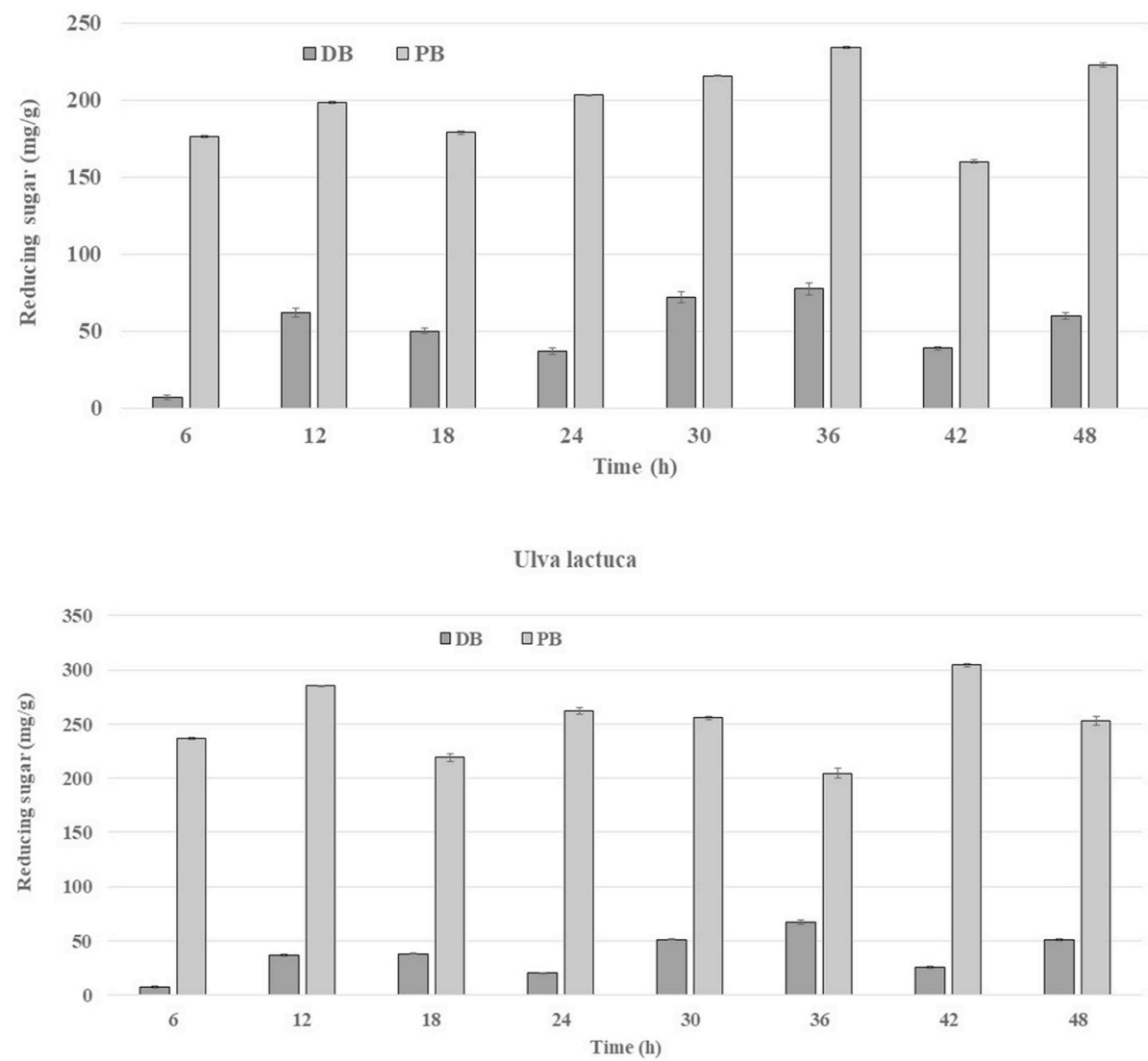

Fig. 6. a) Enzyme hydrolysis for direct biomass (DB) and acid pretreated biomass (PB) for E.intestinalis. b) Enzyme hydrolysis for direct biomass (DB) and acid pretreated biomass (PB) for U.lactuca.

Table 7

Fermentation of macroalgal feedstock by the process of separate hydrolysis and fermentation (SHF) and Separate hydrolysis and Co-fermentation (SHCF).

\begin{tabular}{clllllllll}
\hline Macroalgal feedstock & Process & Combinations & $\begin{array}{l}\text { Biomass }(\mathrm{g}) \\
\text { DW }\end{array}$ & $\begin{array}{l}\text { Initial sugar } \\
(\mathrm{g})\end{array}$ & $\begin{array}{l}\text { Final sugar } \\
(\mathrm{g})\end{array}$ & $\begin{array}{l}\text { Fermented sugar } \\
(\mathrm{g})\end{array}$ & $\begin{array}{l}\text { Ethanol yield } \\
(\mathrm{g})\end{array}$ & $\begin{array}{l}\text { Theoretical } \\
\text { yield }\end{array}$ & $\begin{array}{l}\text { Efficiency } \\
(\%)\end{array}$ \\
\hline Enteromorpha & SHF & EICY & 50 & 22.5 & 10.71 & 11.79 & 1.40 & 6.01 \\
intestinalis & & EITY & & & 10.13 & 12.37 & 1.63 & 23.4 \\
Ulva lactuca & SHCF & EITYCY & & & 15.09 & 7.41 & 6.82 & 3.78 \\
& SHF & ULCY & & 19.2 & 13.17 & 6.03 & 0.37 & 3.07 & 25.8 \\
& & ULTY & & & 12.72 & 6.48 & 0.52 & 3.31 \\
& SHCF & ULTYCY & & & 13.10 & 6.10 & 0.63 & 3.11 \\
\hline
\end{tabular}

CY: Cashew yeast; TY: Toddy yeast

Table 8

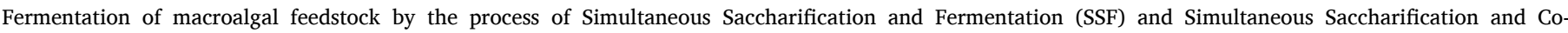
fermentation.

\begin{tabular}{|c|c|c|c|c|c|c|c|c|c|}
\hline Macroalgal feedstock & Process & Combination & $\begin{array}{l}\text { Biomass (g) } \\
\text { DW }\end{array}$ & $\begin{array}{l}\text { Cellulose } \\
(\mathrm{g})\end{array}$ & $\begin{array}{l}\text { Final sugar } \\
(\mathrm{g})\end{array}$ & $\begin{array}{l}\text { Fermented sugar } \\
(\mathrm{g})\end{array}$ & $\begin{array}{l}\text { Ethanol yield } \\
(\mathrm{g})\end{array}$ & $\begin{array}{l}\text { Theoretical } \\
\text { yield }\end{array}$ & $\begin{array}{l}\text { Efficiency } \\
(\%)\end{array}$ \\
\hline \multirow{3}{*}{$\begin{array}{c}\text { Enteromorpha } \\
\text { intestinalis }\end{array}$} & SSF & EICY & 20 & 1.8 & 0.34 & 1.46 & 0.25 & 0.74 & 33.3 \\
\hline & & EITY & & & 0.56 & 1.24 & 0.49 & 0.63 & 77.4 \\
\hline & SSCF & EITYCY & & & 0.52 & 1.28 & 0.27 & 0.65 & 41.8 \\
\hline \multirow[t]{3}{*}{ Ulva lactuca } & $\mathrm{SSF}$ & ULCY & & 1.7 & 0.54 & 1.16 & 0.33 & 0.59 & 54.9 \\
\hline & & ULTY & & & 0.54 & 1.16 & 0.39 & 0.59 & 65.5 \\
\hline & SSCF & ULTYCY & & & 0.66 & 1.04 & 0.60 & 0.53 & 113.0 \\
\hline
\end{tabular}

CY: Cashew yeast; TY: Toddy yeast

combination of EITY produced higher ethanol yield of $0.49 \mathrm{~g} / \mathrm{g}$ achieving $77.4 \%$ efficiency. Simultaneous saccharification and co-fermentation (SSCF) of E. intestinalis produced $0.27 \mathrm{~g} / \mathrm{g}$ of ethanol with $41.8 \%$ efficiency whereas U.lactuca produced efficiency of $113 \%$ indicating fermentation of sugars other than glucan. Candida shehatea, Scheffersomyces stipitis (Pichia stipitis), and Pacchysolen tannophilus are the most promising yeast species for conversion of Xylose [112], which can be used in combination with S.cerevisiae in SSCF process to obtain 
higher ethanol yield [104]. subjected cellulosic residue of Kappaphycus alvarezii along with galactose synthetic medium to SSCF using single strain S.cerevisiae CBS1782 and recorded $64.3 \mathrm{~g} / \mathrm{L}$ of ethanol indicating utilization of galactose sugar along with glucose. Co-fermentation of corn stover using S.cerevisiae and commercial strain TMB3400 yielded $40 \mathrm{~g} / \mathrm{L}$ or ethanol with $59 \%$ theoretical efficiency [74]. S.cerevisiae and S. stipitis were used for SSCF of Rice straw and produced 15.2g/L of ethanol [170].

Seaweeds contain low amounts of polysaccharides composed of glucose. Production of ethanol, therefore, needs to be from carbohydrates including sulphated polysaccharides, sugar acids and sugar alcohols. However, inability of microorganisms in fermenting all sugars present in seaweeds into ethanol is a major drawback. Therefore, isolation of yeast strains to ferment both pentose (C5) and hexose (C6) sugars are vital for achieving higher ethanol yield.

However, recent studies are focusing on non-controversial cellulosic residue following extraction of hydrocolloid from seaweed biomass [60]. But the lower cellulose content of residue prevents it from being a viable feedstock option considering the emergent demand for bioethanol. This necessitates the selection of seaweed species with higher cellulose content together with higher growth rate for sustainable bioethanol production $[89,171]$. Red algae has more agar and carrageenan and brown algae has more algin and lower cellulose compared to green seaweeds, that have cellulose making up to $70 \%$ of their dry weight (as Cladophorales and Ulvales) [176].

It is evident from the experimental results, that green algae are apt as potential feedstock due to higher carbohydrate and cellulose contents. Higher growth rates have been recorded for green seaweeds ranging from 19.15 to $24.25 \%$ when compared to red macroalgae (3-8\%) [89, $177,178]$. Green seaweeds have production potential that is $2-20$ times that of conventional terrestrial energy crops [179]. Red and brown seaweed's lower cellulose content of residue and lower growth rate prevents it from being a viable feedstock to meet the growing demand for bioethanol. Comparison of ethanol yield from other potential macroalgal feedstock are represented in Table 9.

3.3.2. Multivariate analysis of process condition for bioethanol production Downstream process of bioethanol production from macroalgal biomass is dependent on various factors such as dilute acid pretreatment conditions (acid concentration, temperature, incubation time), enzyme hydrolysis conditions ( $\mathrm{pH}$, temperature and incubation time), reducing sugar and fermentation conditions (temperature and incubation time). In order to understand influence of each of these factors in ethanol production, multivariate regression analysis (Table 10) was performed and the probable relationship is given by equation (2). Overall this model explains $97.3 \%$ variation in the data.

$$
\begin{aligned}
Y & =-2.75-4.09\left(X_{1}\right)+0.12\left(X_{2}\right)-0.13\left(X_{3}\right)+10.61\left(X_{4}\right)-0.31\left(X_{5}\right) \\
& -0.04\left(X_{6}\right)+0.32\left(X_{7}\right)-1.23\left(X_{8}\right)-0.12\left(X_{9}\right)
\end{aligned}
$$

Where.

Table 9

\begin{tabular}{|c|c|c|c|c|c|}
\hline Seaweed species & & Reducing sugar $\mathrm{g} / \mathrm{l}$ & Ethanol yield $\mathrm{g} / \mathrm{g}$ & \%Theoretical yield & References \\
\hline \multirow[t]{8}{*}{ Green Seaweeds } & Chaetomorpha media & 27.79 & 0.057 & 10.15 & * \\
\hline & Ulva fasciata & 21.82 & 0.43 & 83.66 & [89] \\
\hline & Ulva lactuca & 1.12 & 0.39 & 77.03 & [94] \\
\hline & Ulva lactuca & 35.43 & 0.23 & 45.62 & * \\
\hline & Ulva pertusa & 43 & 0.43 & 84.36 & [70] \\
\hline & Ulva pertusa & 26 & 0.48 & 93.51 & [97] \\
\hline & Enteromorpha intestinalis & 48.96 & 0.25 & 49.37 & * \\
\hline & Enteromorpha intestinalis & 45.56 & 0.21 & 41.74 & [120] \\
\hline \multirow[t]{17}{*}{ Red Seaweeds } & Gelidium elegans & 49 & 0.38 & 73.63 & {$[70]$} \\
\hline & Gelidium amansii & 43.5 & 0.47 & 92.40 & [108] \\
\hline & & 42.2 & 0.38 & 74.51 & [126] \\
\hline & & 7.93 & 0.42 & 82.34 & [172] \\
\hline & & 7.93 & 0.48 & 93.46 & \\
\hline & Gracilaria verrucosa & 34.63 & 0.43 & 84.31 & [60] \\
\hline & & 19.70 & 0.43 & 84.31 & [110] \\
\hline & Gracilaria corticata & 57.90 & 0.01 & 0.98 & * \\
\hline & Gracilaria salicornia & 13.8 & 0.079 & 15.49 & [173] \\
\hline & Gracilaria sp. & 11.46 & 0.42 & 82.35 & [132] \\
\hline & Grateloupia lithophila & 44.45 & 0.09 & 17.85 & * \\
\hline & Gelidium pusillum & 36.96 & 0.04 & 8.49 & * \\
\hline & Eucheuma cottonii (Kappaphycus alvarezii) & 11 & 0.45 & 89.13 & [88] \\
\hline & & 81 & 0.45 & 88.24 & [104] \\
\hline & & 20.4 & 0.21 & 41.18 & [164] \\
\hline & & 51.9 & 0.42 & 82.36 & [117] \\
\hline & Palmaria palmata & 21.84 & 0.173 & 33.92 & [133] \\
\hline \multirow[t]{15}{*}{ Brown Seaweeds } & Alaria crassifolia & 67.20 & 0.38 & 74.40 & [70] \\
\hline & Laminaria hyperborea & 30 & 0.43 & 84.31 & [114] \\
\hline & Padina tetrastromatica & 17.9 & 0.01 & 2.53 & * \\
\hline & Sargassum sagamianum & 25.9 & 0.386 & 75.69 & [116] \\
\hline & Sargassum sagamianum & 2.55 & 0.89 & 174.55 & [174] \\
\hline & Sargassum sagamianum & 19.8 & 0.35 & 69.32 & [125] \\
\hline & Sargassum ilcifolium & 27.04 & 0.05 & 9.60 & * \\
\hline & Sargassum fluvellum & 9.6 & & & [54] \\
\hline & Saccharina japonica & 6.72 & 0.343 & 67.25 & [163] \\
\hline & Saccharina japonica & 34 & 0.41 & 80.74 & [103] \\
\hline & Saccharina japonica & 45.6 & 0.17 & 33.11 & [52] \\
\hline & Saccharina japonica & 75 & 0.34 & 67.45 & [116] \\
\hline & Saccharina latissima & 35 & 0.45 & 88.24 & [36] \\
\hline & Undaria pinnatifida & 42.9 & 0.22 & 43.05 & [120] \\
\hline & Undaria pinnatifida & 20 & 0.144 & 28.24 & [107] \\
\hline Seagrass & Zosteria marina & 92 & 0.059 & 11.5 & [175] \\
\hline
\end{tabular}

Comparison of reducing sugar, ethanol yield and percent theoretical yield from various macroalgal biomass.

*Current work. 
Table 10

Coefficients and SE values of multivariate regression analysis.

\begin{tabular}{llll}
\hline Process & Process condition & Coefficients & Standard Error \\
\hline Dilute acid pretreatment & Concentration & -4.09 & 1.14 \\
& Temperature & 0.12 & 0.29 \\
& Incubation Time & -0.13 & 0.67 \\
Enzyme hydrolysis & pH & $10.61^{*}$ & $2.44^{*}$ \\
& Temperature & -0.31 & 0.16 \\
& Incubation Time & -0.04 & 0.02 \\
\multirow{3}{*}{ Fermentation process } & Reducing sugar & $0.32^{*}$ & $0.04^{*}$ \\
& Temperature & -1.23 & 2.09 \\
& Incubation Time & $-0.12^{*}$ & $0.02^{*}$ \\
\hline
\end{tabular}

$* \mathrm{p}<0.05$.

Y: Ethanol $\mathrm{g} / \mathrm{L}, \mathrm{X}_{1}$ : Acid concentration $(\mathrm{mM}), \mathrm{X}_{2}$ : Acid hydrolysis Temperature $\left({ }^{\circ} \mathrm{C}\right), \mathrm{X}_{3}$ : Acid hydrolysis incubation time (min), $\mathrm{X}_{4}$ : buffer $\mathrm{pH}, \mathrm{X}_{5}$ : Enzyme hydrolysis temperature $\left({ }^{\circ} \mathrm{C}\right), \mathrm{X}_{6}$ : Enzyme hydrolysis incubation time $(\mathrm{h}), \mathrm{X}_{7}$ : Reducing sugar in $(\mathrm{g} / \mathrm{L}), \mathrm{X}_{8}$ : Fermentation temperature $\left({ }^{\circ} \mathrm{C}\right), \mathrm{X}_{9}$ : Fermentation time (h)

This analysis highlights that process conditions such as; acid pretreatment temperature, buffer $\mathrm{pH}$ and reducing sugar concentration affects the ethanol yield (Eq. (2)). The increase in hydrolysis temperature during acid catalyzed reaction would also enhance the sugar production and decomposition [180,181]. Pretreatment temperature plays a vital role in sugar release as higher temperatures often leads to the formation of inhibitor, which is detrimental to the fermentative microorganisms leading to reduced ethanol yields $[69,181]$. Enzymes consists of ionic groups on their active sites which varies along with the $\mathrm{pH}$ resulting in changes in the activity of the enzyme, its structure, reaction rate and the product formation [182]. Therefore, $\mathrm{pH}$ of the reaction medium or buffer needs to be optimum for higher enzyme activity [183, 184]. Fermentation process is slower in low sugar medium, whereas the process increases in the medium containing $15-20 \mathrm{~g} / \mathrm{L}$ of sugar and remains stable up to $200 \mathrm{~g} / \mathrm{L}$. Medium with $200 \mathrm{~g} / \mathrm{L}$ to $300 \mathrm{~g} / \mathrm{L}$ of sugar concentration lowers the growth of yeast microorganisms [185-187]. However, higher concentration of fermentable sugars yield higher ethanol, whereas non-fermentable sugars (pentose) can affect the fermentation yield due to lack of transport system in yeasts.

\section{Scope and opportunities for macroalgal cultivation}

Macroalgal cultivation can be attempted in India by taking the advantage of 2.172 million $\mathrm{km}^{2}$ exclusive economic zone (including Andaman and Nicobar islands) as well as abandoned aquaculture ponds. Aghanashini estuary (Lat $14.391^{\circ}-14.585^{\circ} \mathrm{N}$; Long $74.304^{\circ}-74.516^{\circ} \mathrm{E}$ ) situated in Kumta taluk, Karnataka consists of such aquaculture ponds called gazni, which serves as potential site (Fig. 7) for macroalgal cultivation [134]. U.lactuca and E.intestinalis abundantly grows in this estuary during all the season and E.intestinalis naturally occurring in gazni ponds are mostly discarded as waste. Ulva and Enteromorpha genus possess a blade-like or filamentous morphology, which can tolerate wide range of environmental conditions such as temperature upto $40^{\circ} \mathrm{C}$ [51] and tolerate salinities in the range of $10-60 \mathrm{ppt}$ [188] and resulting in higher [135].

The spatial extent of gazani lands in Aghanashini estuary (Fig. 7) is about 2000 ha (much of it not being used for rice cultivation now) and area of 1000 ha could be considered for algal cultivation during the late monsoon months and subsequently, these lands may be used for shrimp culturing or utilized for other forms of fisheries. The algal production happens indeed without any external input of nutrients, and therefore the gaznis hold very good potential for ethanol production, prior to the commencement of fishery operations, and before salinity rises substantially with the cessation of the rainy season. The algal harvests can be effectively made from any gazni at biweekly intervals, two weeks' time considered fairly good for harvestable regrowth. It means effectively 1000 ha area are available for algal harvests every week. The lean season for fishery (of prawns and fish mainly) alone needs to be utilized for this purpose, so that prospects for ethanol production, by no means, could come in the way of food production. These 1000 ha of aquaculture areas could be effectively available for algal harvests during the off-season, which might benefit about 2500 small farmers, who were once rice cultivators, who had permitted their erstwhile fields to be converted into shrimp farms, which are not in suitable condition for reintroduction of rice without making substantial structural changes. These gazni lands also exhibit positive correlation with water temperature, air and salinity which influences the growth of diatoms such as Pleurosigma balticum, Melosira sp., Nitzschia sigma and Nitzchia spp. that are potential candidates for biodiesel production [189].

Cultivation of Ulva and Enteromorpha is estimated to produce annual biomass of $45 \mathrm{t} / \mathrm{ha}$ [179] and $100 \mathrm{t} / \mathrm{ha}$ [51] respectively, which is 2-20 times the production potential of first and second generation feedstock and 3 times the production of brown algae in temperate waters [179]. Commercial cultivation of these seaweeds largely focuses on high-value food (aonori) and aquaculture feed production. Ammonium are abundantly present in aquaculture effluent, which is readily assimilated by Enteromorpha and Ulva in the range of $50-90 \mu \mathrm{molN} / \mathrm{g}$ DW h, which makes it feasible to cultivate these algae in aquaculture effluents qualifying as species for bioremediation process [190,191]. However, sporadic sporulation of Ulva leads to loss of biomass due to which attempts of cultivating at large scale has failed, also environmental factors responsible for these sporulation have not yet been completely explored

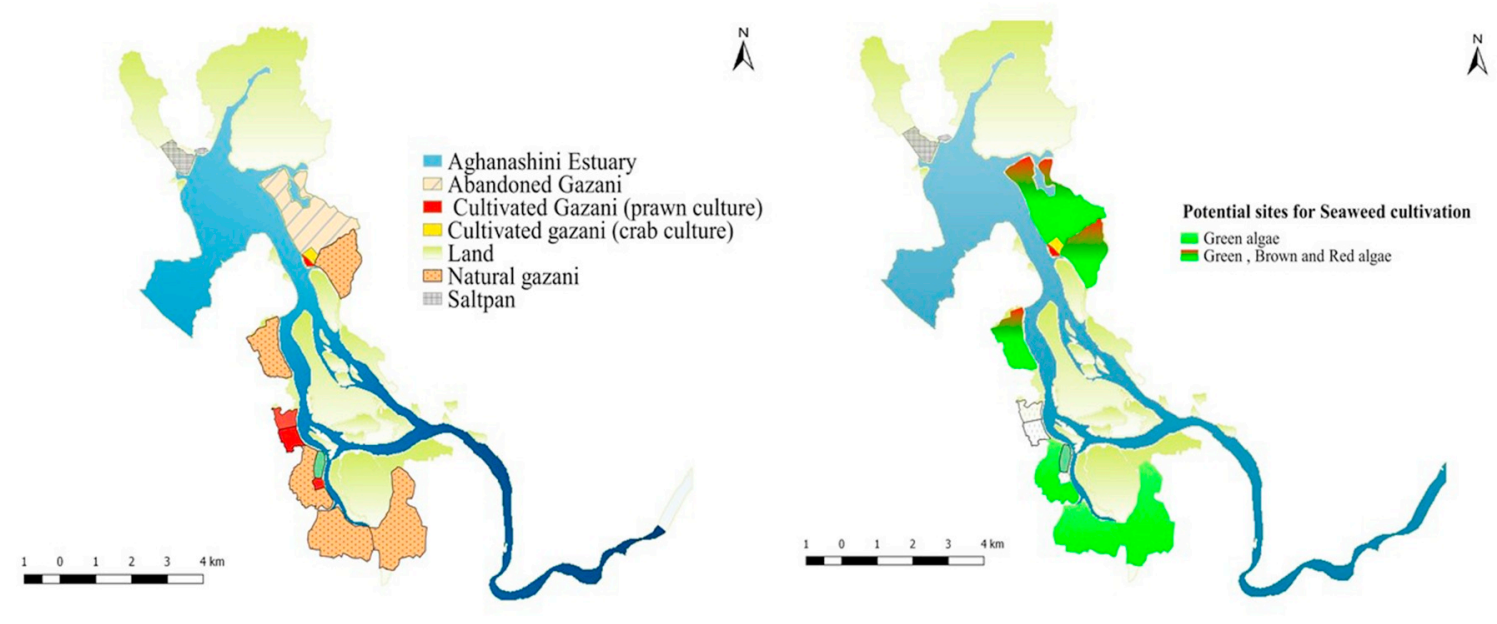

Fig. 7. Potential sites for macroalgal cultivation in Aghanashini Estuary. 
[190]. This can be overcome by technique [135], involving artificial seeding under controlled conditions. This allows control over higher seeding density and consequently biomass production. Seeding density of 621,000 swarmers/m and nursery period of five days were quantified as key factors affecting the growth and biomass yield of Ulva sp. This study also highlights the shorter nursery period and culture cycles required for green seaweeds when compared to red and brown seaweeds.

Large-scale cultivation of macroalgae in open ocean eliminates the need for external inputs such as $\mathrm{CO}_{2}$ cylinders, monitoring of temperature or $\mathrm{pH}$ alteration. However in controlled conditions, all these parameters play a crucial role in sustaining biomass productivity. Algae acquire carbon in the form of $\mathrm{CO}_{2}$ or bicarbonates, at $\mathrm{pH} 8$, seawater has alkalinity of $2.3 \mathrm{meq}$ which allows only $0.5 \mathrm{mM}$ of $\mathrm{CO}_{2}$ or $6 \mathrm{mg} / \mathrm{l}$ of C to be absorbed from the seawater. In order to increase the level of $\mathrm{CO}_{2}$ absorption $\mathrm{pH}$ needs to be increased to nearly 9 which is not feasible as it slows down the photosynthesis [192].In a study [193], brown seaweeds (Sargassum sp.) were cultivated at different $\mathrm{pH}$ and temperature and was observed that higher biomass productivity obtained at ambient $\mathrm{pH}$ of 7-8.2, indicating that low $\mathrm{pH}$ values affected the growth of the algae.

The seaweed industry in India is still at infancy, functioning more like a cottage industry. Seaweeds are collected from the natural stock mainly for the production of agar without any regulations [194]. Macroalgal biomass in addition to being potential feedstock for bioethanol production, also serves as a good food supplement. Enteromorpha was tested as nutritional supplement in preparation of Indian snacks, which resulted in higher iron and calcium content along with increase in proteins, vitamins and dietary fibres [195]. Macroalgal protein, dietary fibres and phytochemicals are utilized in order to enhance the nutritional quality of the food products. Complete utilization of macroalgal biomass into producing biofuel and value added products has potential to ensure India's energy and food security [134]. The study presents the scope to utilize macroalgal biomass in producing value added products in addition to bioethanol production, bringing resilience to the Industry and improving their economics and usefulness. Prospects of bioethanol with the value added products would support the livelihood of rural population, while aiding as the potential feedstock for biorefinery [36, 196].

\section{Conclusion}

The growing need to cater the energy demand coupled with the urge to mitigate GHG footprint in the energy sector has necessitated inventorying of renewable and sustainable energy alternatives. Green seaweeds have the potential to serve as a renewable and sustainable feedstock for bioethanol production. Dilute acid, $\mathrm{H}_{2} \mathrm{SO}_{4}$ is an appropriate pretreatment method for extraction of sugars from algal biomass. Algal biomass pretreated using dilute acid yields higher sugar during enzyme hydrolysis by exposing cellulose fibres for enzyme degradation. Neutralization using $\mathrm{Na}_{2} \mathrm{CO}_{3}$ exhibited lower sugar removal for U.lactuca (39.8\%) and E.intestinalis (14.7\%). Green seaweeds U.lactuca and E. intestinalis are viable feedstock for bioethanol production due to higher carbohydrate content of $62.15 \%$ and $40.1 \%$ respectively. Saccharification and Fermentation (SSF) process yielded higher conversion efficiency compared to SHF (Separate hydrolysis and fermentation) process and SSF achieved higher efficiency for U.lactuca indicating fermentation of more than one sugar present in the medium. Toddy yeast strain exhibited higher efficacy in fermentation of E.intestinalis hydrolysate in both SHF and SSF process achieving $25.8 \%$ and $77.4 \%$ efficiency respectively. Macroalgal biomass has potential to produce various value added products of commercial significance in addition to the production of biofuels. The study highlights the scope for bioethanol from macroalgae and also the availability of potential sites for cultivation. The comprehensive knowledge of macro algal resources distribution, seasonality and biochemical composition through field survey and choice of appropriate enzyme and yeast would aid in realizing the path of the sustainable, economical and commercially viable biofuel.

\section{Data and accessibility}

Data used in the analyses are compiled from the field. Data is anlysed and organized in the form of table, which are presented in the manuscript. Also, synthesized data are archived at http://wgbis.ces.iisc.ernet. in/energy/water/paper/researchpaper2.html\#ce, http://wgbis.ces.iisc. ernet.in/biodiversity/

\section{Competing interests}

We have no competing interests either financial or non-financial.

\section{Authors contribution}

Ramachandra T V: data analysis and interpretation of data; revising the article critically for important intellectual content; final editing Deepthi H: Isolation and characterisation, Design of the fermentation experiment, Carrying out experiments, analysis and interpretation of data; and Paper writing.

\section{Funding}

This research was supported with the grant (i) ISRO-IISc Space Technology Cell [ISTC/BES/TVR/389] (ii) Gajanana and Madhavi Hegde [CES/TVR/GJH001] endowment for biofuel research; (iii) Indian Institute of Science.

\section{Research ethics}

The publication is based on the original research and has not been submitted elsewhere for publication or web hosting.

\section{Animal ethics}

The research does not involve either humans, animals or tissues.

\section{Permission to carry out fieldwork}

Our research is commissioned by the Ministry of Science and Technology (NRDMS Division), Government of India and hence no further permission is required as the field work was carried out in the nonrestricted areas/protected areas.

\section{Acknowledgement}

The authors are grateful to (i) ISRO-IISc Space Technology Cell [ISTC/BES/TVR/389] (ii) Gajanana and Madhavi Hegde [CES/TVR/ GJH001] endowment for biofuel research for the financial support and (iii) the NRDMS Division, Ministry of Science and Technology, Government of India [CES/TVR/DST1045]; (iv) Indian Institute of Science [R1011] for the infrastructure support and colleagues at EWRG, IISc field station, Kumta for assistance during the field sampling.

We thank Sreekanth Naik and Gayatri Naik for the assistance during the field data collection. We thank all the stakeholders of Aghanashini estuary for actively taking part in the scientific discussions and cooperation during field data compilation. We are grateful to the official languages section at IISc for the assistance in language editing.

\section{References}

[1] Goli A, Shamiri A, Talaiekhozani A, Eshtiaghi N, Aghamohammadi N, Aroua MK. An overview of biological processes and their potential for $\mathrm{CO} 2$ capture. J Environ Manag 2016;183:41-58. https://doi.org/10.1016/J. JENVMAN.2016.08.054. 
[2] Raheem A, Prinsen P, Vuppaladadiyam AK, Zhao M, Luque R. A review on sustainable microalgae based biofuel and bioenergy production: recent developments. J Clean Prod 2018;181:42-59. https://doi.org/10.1016/j. jclepro.2018.01.125.

[3] Hirsch RL, Bezdek R, Wendling R. Peaking of world oil production: impacts, mitigation, \& risk management. 2005.

[4] Ramachandra TV, Bharath HA, Kulkarni G, Han SS. Municipal solid waste: generation, composition and GHG emissions in Bangalore, India. Renew Sustain Energy Rev 2018;82:1122-36. https://doi.org/10.1016/j.rser.2017.09.085.

[5] Ramachandra TV, Bajpai V, Kulkarni G, Aithal BH, Han SS. Economic disparity and $\mathrm{CO} 2$ emissions: the domestic energy sector in Greater Bangalore, India. Renew Sustain Energy Rev 2017;67:1331-44. https://doi.org/10.1016/j. rser.2016.09.038.

[6] Bölük G, Mert M. Fossil \& renewable energy consumption, GHGs (greenhouse gases) and economic growth: evidence from a panel of EU (European Union) countries. Energy 2014;74:439-46. https://doi.org/10.1016/j. energy.2014.07.008.

[7] Hahn-Hägerdal B, Galbe M, Gorwa-Grauslund MF, Lidén G, Zacchi G. Bio-ethano - the fuel of tomorrow from the residues of today. Trends Biotechnol 2006;24: 549-56. https://doi.org/10.1016/j.tibtech.2006.10.004.

[8] Tripathi L, Mishra AK, Dubey AK, Tripathi CB, Baredar P. Renewable energy: an overview on its contribution in current energy scenario of India. Renew Sustain Energy Rev 2016;60:226-33. https://doi.org/10.1016/j.rser.2016.01.047.

[9] Hirst E. Integrating wind output with bulk power operations and wholesale electricity markets. Wind Energy 2002;5:19-36. https://doi.org/10.1002/we.57.

[10] Leahy PG, Foley AM. Wind generation output during cold weather-driven electricity demand peaks in Ireland. Energy 2012;39:48-53. https://doi.org/ 10.1016/j.energy.2011.07.013.

[11] Huang H, Li F. Bidding strategy for wind generation considering conventional generation and transmission constraints. J Mod Power Syst Clean Energy 2015;3 51-62. https://doi.org/10.1007/s40565-015-0100-8.

[12] Sikarwar VS, Zhao M, Fennell PS, Shah N, Anthony EJ. Progress in biofuel production from gasification. Prog Energy Combust Sci 2017;61:189-248. https://doi.org/10.1016/j.pecs.2017.04.001.

[13] Lipscy PY, Kushida KE, Incerti T. The fukushima disaster and Japan's nuclear plant vulnerability in comparative perspective. Environ Sci Technol 2013;47: 6082-8. https://doi.org/10.1021/es4004813.

[14] Nuclear backlash forces Merkel to rethink energy policy | Germany| News and indepth reporting from Berlin and beyond | DW | 14.03. 2011 (accessed January 1 , 2019), https://www.dw.com/en/nuclear-backlash-forces-merkel-to-rethinkenergy-policy/a-14909851.

[15] Annual report 2017-18. Ministry of Petroleum \& Natural Gas (MoPNG) Government of India; 2018.

[16] Kumar A, Kumar K, Kaushik N, Sharma S, Mishra S. Renewable energy in India: current status and future potentials. Renew Sustain Energy Rev 2010;14: 2434-42. https://doi.org/10.1016/j.rser.2010.04.003.

[17] Ramachandra TV, Shwetmala. Decentralised carbon footprint analysis for opting climate change mitigation strategies in India. Renew Sustain Energy Rev 2012;16: 5820-33. https://doi.org/10.1016/j.rser.2012.05.035.

[18] Aljerf L. Green technique development for promoting the efficiency of pulp slurry reprocess. 2016.

[19] Armstrong RC, Wolfram C, de Jong KP, Gross R, Lewis NS, Boardman B, et al. The frontiers of energy. Nat Energy 2016;1:15020. https://doi.org/10.1038/ nenergy.2015.20.

[20] Ramachandra TV, Shruthi BV. Spatial mapping of renewable energy potential. Renew Sustain Energy Rev 2007;11:1460-80. https://doi.org/10.1016/j. rser.2005.12.002.

[21] Ramachandra TV, Jain R, Krishnadas G. Hotspots of solar potential in India. Renew Sustain Energy Rev 2011;15:3178-86. https://doi.org/10.1016/j. rser.2011.04.007.

[22] Bhattacharyya SC. Energy access problem of the poor in India: is rural electrification a remedy? Energy Policy 2006;34:3387-97. https://doi.org/ 10.1016/j.enpol.2005.08.026.

[23] McKendry P. Energy production from biomass (part 2): conversion technologies. Bioresour Technol 2002;83:47-54. https://doi.org/10.1016/S0960-8524(01) 00119-5.

[24] Kumar A, Kumar N, Baredar P, Shukla A. A review on biomass energy resources, potential, conversion and policy in India. Renew Sustain Energy Rev 2015;45: 530-9. https://doi.org/10.1016/j.rser.2015.02.007.

[25] Naik SN, Goud VV, Rout PK, Dalai AK. Production of first and second generation biofuels: a comprehensive review. Renew Sustain Energy Rev 2010;14:578-97. https://doi.org/10.1016/j.rser.2009.10.003.

[26] Ramachandra TV. Mapping of fuelwood trees using geoinformatics. Renew Sustain Energy Rev 2010;14:642-54. https://doi.org/10.1016/J. RSER.2009.10.007.

[27] Ramachandra TV, Joshi NV, Subramanian DK. Present and prospective role of bioenergy in regional energy system. Renew Sustain Energy Rev 2000;4:375-430. https://doi.org/10.1016/S1364-0321(00)00002-2.

[28] Ramachandra TV, Kamakshi G, Shruthi BV. Bioresource status in Karnataka. Renew Sustain Energy Rev 2004;8:1-47. https://doi.org/10.1016/j. rser.2003.09.001.

[29] Ö D, Inan B. An overview of bioethanol production from algae. Biofuels-Status Perspect 2015;141-62. https://doi.org/10.5772/57353.

[30] Zhu JY, Pan XJ. Woody biomass pretreatment for cellulosic ethanol production: technology and energy consumption evaluation. Bioresour Technol 2010;101: 4992-5002. https://doi.org/10.1016/j.biortech.2009.11.007.
[31] Sticklen MB. Plant genetic engineering for biofuel production: towards affordable cellulosic ethanol. Nat Rev Genet 2008;9:433-43. https://doi.org/10.1038/ nrg2336.

[32] Maeda M, Tokimatsu K, Mori S. A global supply-demand balance model to assess potential CO2Emissions and woody biofuel supply from increased crop production. Energy Procedia 2015;75:2865-70. https://doi.org/10.1016/j. egypro.2015.07.575.

[33] Gasparatos A, Stromberg P, Takeuchi K. Sustainability impacts of first-generation biofuels. Anim Front 2013;3:12-26. https://doi.org/10.2527/af.2013-0011.

[34] Ramachandra TV, Aithal BH, Sreejith K. GHG footprint of major cities in India. Renew Sustain Energy Rev 2015;44:473-95. https://doi.org/10.1016/j. rser.2014.12.036.

[35] Subhadra B, Edwards M. An integrated renewable energy park approach for algal biofuel production in United States. Energy Policy 2010;38:4897-902. https:// doi.org/10.1016/j.enpol.2010.04.036.

[36] Adams JM, Gallagher JA, Donnison IS. Fermentation study on saccharina latissima for bioethanol production considering variable pre-treatments. J Appl Phycol 2009;21:569-74. https://doi.org/10.1007/s10811-008-9384-7.

[37] Behera S, Singh R, Arora R, Sharma NK, Shukla M, Kumar S. Scope of algae as third generation biofuels. Front Bioeng Biotechnol 2015;2:1-13. https://doi.org/ 10.3389/fbioe. 2014.00090.

[38] Demirbas A. Biofuels sources, biofuel policy, biofuel economy and global biofuel projections. Energy Convers Manag 2008;49:2106-16. https://doi.org/10.1016/ j.enconman.2008.02.020.

[39] John RP, Anisha GS, Nampoothiri KM, Pandey A. Micro and macroalgal biomass: a renewable source for bioethanol. Bioresour Technol 2011;102:186-93. https:// doi.org/10.1016/j.biortech.2010.06.139.

[40] Ramachandra TV, Durga Madhab M, Shilpi S, Joshi NV. Algal biofuel from urban wastewater in India: scope and challenges. Renew Sustain Energy Rev 2013;21: 767-77. https://doi.org/10.1016/j.rser.2012.12.029.

[41] Odum WE, Heald EJ. Trophic analyses of an estuarine mangrove community. Bull Mar Sci 1972;22:671-738. https://doi.org/10.12691/marine-2-1-3.

[42] Kraan S. Mass-cultivation of carbohydrate rich macroalgae, a possible solution for sustainable biofuel production. Mitig Adapt Strategies Glob Change 2013;18: 27-46. https://doi.org/10.1007/s11027-010-9275-5.

[43] Milledge JJ, Smith B, Dyer PW, Harvey P. Macroalgae-derived biofuel: a review of methods of energy extraction from seaweed biomass. Energies 2014;7:7194-222. https://doi.org/10.3390/en7117194.

[44] Ramachandra TV, Mahapatra DM, Karthick B, Gordon R. Milking diatoms for sustainable energy: biochemical engineering versus gasoline-secreting diatom solar panels. Ind Eng Chem Res 2009;48:8769-88. https://doi.org/10.1021/ ie900044j.

[45] Smith VH, Sturm BSM, deNoyelles FJ, Billings SA. The ecology of algal biodiesel production. Trends Ecol Evol 2010;25:301-9. https://doi.org/10.1016/j. tree.2009.11.007.

[46] Hurd CL, Harrison PJ, Bischof K, Lobban CS. Seaweed ecology and physiology. Cambridge University Press; 2014.

[47] McHugh DJ. Seaweeds uses as human foods. A Guid to Seaweed Ind 2003;105. ISBN 92-5-104958-0.

[48] Pereira L, Neto JM. Marine algae: biodiversity, taxonomy, environmental assessment, and biotechnology. CRC Press; 2014

[49] Rajkumar R, Yaakob Z, Takriff MS. Potential of the micro and macro algae for biofuel production: a brief review. BioResources 2014;9:1606-33. https://doi. org/10.15376/biores.9.1.1606-1633.

[50] Yanagisawa M, Kawai S, Murata K. Strategies for the production of high concentrations of bioethanol from seaweeds: production of high concentrations of bioethanol from seaweeds. Bioengineered 2013;4:224-35. https://doi.org/ 10.4161/bioe.23396.

[51] Moll B, Deikman J. Enteromorpha clathrata: a potential seawater-irrigated crop. Bioresour Technol 1995;52:255-60. https://doi.org/10.1016/0960-8524(95) 00036-E.

[52] Jang JS, Cho YK, Jeong GT, Kim SK. Optimization of saccharification and ethanol production by simultaneous saccharification and fermentation (SSF) from seaweed, Saccharina japonica. Bioproc Biosyst Eng 2012;35:11-8. https://doi. org/10.1007/s00449-011-0611-2.

[53] Harun MKRD. Enzymatic hydrolysis of microalgal biomass for bioethanol production. Chem Eng J 2011;168:1079-84. https://doi.org/10.1016/j. cej.2011.01.088

[54] Jung KA, Lim SR, Kim Y, Park JM. Potentials of macroalgae as feedstocks for biorefinery. Bioresour Technol 2013;135:182-90. https://doi.org/10.1016/j. biortech.2012.10.025.

[55] Wei N, Quarterman J, Jin YS. Marine macroalgae: an untapped resource for producing fuels and chemicals. Trends Biotechnol 2013;31:70-7. https://doi.org/ 10.1016/j.tibtech.2012.10.009.

[56] Borines MG, de Leon RL, Cuello JL. Bioethanol production from the macroalgae Sargassum spp. Bioresour Technol 2013;138:22-9. https://doi.org/10.1016/j . biortech.2013.03.108.

[57] Kjellman FR. Phaeophyceae (fucoideae). Die Nat Pflanzenfamilien I Teil 1891;2: 176-92.

[58] Pascher A. Uber Flagellaten und Algen. Ber Dtsch Bot Ges 1914;32:136-60.

[59] Elizabeth Percival RHM. Chemistry and enzymology of marine algal polysaccharides. Q Rev Biol 2004;44. https://doi.org/10.1086/406101. 229-229.

[60] Kumar S, Gupta R, Kumar G, Sahoo D, Chander R. Biore source Tec hnology Bioethanol production from Gracilaria verrucosa , a red alga , in a biorefinery 
approach. Bioresour Technol 2013;135:150-6. https://doi.org/10.1016/j. biortech.2012.10.120.

[61] Smith GM. Cryptogamic botany. Volume I, Algae and fungi, vol. I. Cryptogam Bot; 1938. Algae Fungi.

62] El-Dalatony MM, Salama ES, Kurade MB, Hassan SHA, Oh SE, Kim S, et al. Utilization of microalgal biofractions for bioethanol, higher alcohols, and biodiesel production: a review. Energies 2017;10:1-19. https://doi.org/10.3390/ en10122110.

[63] Lin F, Waters CL, Mallinson RG, Lobban LL, Bartley LE. Relationships between biomass composition and liquid products formed via pyrolysis. Front Energy Res 2015;3. https://doi.org/10.3389/fenrg.2015.00045.

[64] Pauly M, Keegstra K. Cell-wall carbohydrates and their modification as a resource for biofuels. Plant J 2008;54:559-68. https://doi.org/10.1111/j.1365313X.2008.03463.x.

[65] Machineni L. Lignocellulosic biofuel production: review of alternatives. Biomass Convers Biorefinery 2019. https://doi.org/10.1007/s13399-019-00445-x.

[66] Agbor VB, Cicek N, Sparling R, Berlin A, Levin DB. Biomass pretreatment: fundamentals toward application. Biotechnol Adv 2011;29:675-85. https://doi. org/10.1016/j.biotechadv.2011.05.005.

[67] Ibrahim HAH. Pretreatment of straw for bioethanol production. Energy Procedia 2012;14:542-51. https://doi.org/10.1016/j.egypro.2011.12.973.

[68] Lee HV, Hamid SBA, Zain SK. Conversion of lignocellulosic biomass to nanocellulose: structure and chemical process. ScientificWorldJournal 2014; 2014:631013. https://doi.org/10.1155/2014/631013.

[69] Hamelinck CN, Van Hooijdonk G, Faaij APC. Ethanol from lignocellulosic biomass: techno-economic performance in short-, middle- and long-term. Biomas Bioenergy 2005;28:384-410. https://doi.org/10.1016/j.biombioe.2004.09.002.

[70] Yanagisawa M, Nakamura K, Ariga O, Nakasaki K. Production of high concentrations of bioethanol from seaweeds that contain easily hydrolyzable polysaccharides. Process Biochem 2011;46:2111-6. https://doi.org/10.1016/j. procbio.2011.08.001.

[71] Kristensen JB, Thygesen LG, Felby C, Jørgensen H, Elder T. Cell-wall structural changes in wheat straw pretreated for bioethanol production. Biotechnol Biofuels 2008;1:1-9. https://doi.org/10.1186/1754-6834-1-5.

[72] Nandakumar MP, Thakur MS, Raghavarao KSMS, Ghildyal NP. Mechanism of solid particle degradation by Aspergillus Niger in solid state fermentation. Process Biochem 1994;29:545-51. https://doi.org/10.1016/0032-9592(94)80016-2.

[73] Chen H, Zhou D, Luo G, Zhang S, Chen J. Macroalgae for biofuels production progress and perspectives. Renew Sustain Energy Rev 2015;47:427-37. https:// doi.org/10.1016/j.rser.2015.03.086.

[74] Öhgren K, Bengtsson O, Gorwa-Grauslund MF, Galbe M, Hahn-Hägerdal B, Zacchi G. Simultaneous saccharification and co-fermentation of glucose and xylose in steam-pretreated corn stover at high fiber content with Saccharomyces cerevisiae TMB3400. J Biotechnol 2006;126:488-98. https://doi.org/10.1016/j. jbiotec.2006.05.001.

[75] Abo-State MA, Ragab AME, EL-Gendy NS, Farahat LA, Madian HR. Effect of different pretreatments on egyptian sugar-cane bagasse saccharification and bioethanol production. Egypt J Pet 2013;22:161-7. https://doi.org/10.1016/j. ejpe.2012.09.007.

[76] Aggarwal NK, Niga P, Singh D, Yadav BS. Process optimization for the production of sugar for the bioethanol industry from tapioca, a non-conventional source of starch. World J Microbiol Biotechnol 2001;17:783-7. https://doi.org/10.1023/A 1013500602881.

[77] Kucharska K, Rybarczyk P, Hołowacz I, Łukajtis R, Glinka M, Kamiński M. Pretreatment of lignocellulosic materials as substrates for fermentation processes. Molecules 2018;23:2937. https://doi.org/10.3390/molecules23112937.

[78] Binod P, Kuttiraja M, Archana M, Janu KU, Sindhu R, Sukumaran RK, et al. High temperature pretreatment and hydrolysis of cotton stalk for producing sugars for bioethanol production. Fuel 2012;92:340-5. https://doi.org/10.1016/j. fuel.2011.07.044.

[79] Banerjee S, Sen R, Pandey RA, Chakrabarti T, Satpute D, Giri BS, et al. Evaluation of wet air oxidation as a pretreatment strategy for bioethanol production from rice husk and process optimization. Biomass Bioenergy 2009;33:1680-6. https:// doi.org/10.1016/j.biombioe.2009.09.001.

[80] Ghadiryanfar M, Rosentrater KA, Keyhani A, Omid M. A review of macroalgae production, with potential applications in biofuels and bioenergy. Renew Sustain Energy Rev 2016;54:473-81. https://doi.org/10.1016/j.rser.2015.10.022.

81] Maneein S, Milledge JJ, Nielsen BV, Harvey PJ. A review of seaweed pretreatment methods for enhanced biofuel production by anaerobic digestion or fermentation. Fermentatio 2018;4:100. https://doi.org/10.3390/ fermentation 4040100.

[82] Noparat P, Prasertsan P, Pan X. Dilute acid pretreatment of oil palm trunk biomass at high temperature for enzymatic hydrolysis. Energy Procedia 2015;79: 924-9. https://doi.org/10.1016/J.EGYPRO.2015.11.588.

[83] Hendriks ATWM, Zeeman G. Pretreatments to enhance the digestibility of lignocellulosic biomass. Bioresour Technol 2009;100:10-8. https://doi.org/ 10.1016/j.biortech.2008.05.027.

[84] Hirasawa K, Uchimura K, Kashiwa M, Grant WD, Ito S, Kobayashi T, et al. Saltactivated endoglucanase of a strain of alkaliphilic Bacillus agaradhaerens. Antonie van Leeuwenhoek. Int J Gen Mol Microbiol 2006;89:211-9. https://doi org/10.1007/s10482-005-9023-0.

[85] Yazdani P, Karimi K, Taherzadeh M. Improvement of enzymatic hydrolysis of a marine macro-alga by dilute acid hydrolysis pretreatment. World Renew Energy 2011:186-91. https://doi.org/10.3384/ecp11057186.
[86] Amezcua-Allieri MA, Sánchez Durán T, Aburto J. Study of chemical and enzymatic hydrolysis of cellulosic material to obtain fermentable sugars. J Chem 2017;2017. https://doi.org/10.1155/2017/5680105.

[87] Tan IS, Lee KT. Enzymatic hydrolysis and fermentation of seaweed solid wastes for bioethanol production: an optimization study. Energy 2014;78:53-62. https://doi.org/10.1016/j.energy.2014.04.080.

[88] Trivedi N, Gupta V, Reddy CRK, Jha B. Enzymatic hydrolysis and production of bioethanol from common macrophytic green alga Ulva fasciata Delile. Bioresour Technol 2013;150:106-12. https://doi.org/10.1016/j.biortech.2013.09.103.

[89] Hebbale D, Bhargavi R, Ramachandra TV. Saccharification of macroalgal polysaccharides through prioritized cellulase producing bacteria. Heliyon 2019;5: e01372. https://doi.org/10.1016/j.heliyon.2019.e01372.

[90] Juturu V, Wu JC. Microbial cellulases: engineering, production and applications. Renew Sustain Energy Rev 2014;33:188-203. https://doi.org/10.1016/j rser.2014.01.077.

[91] Bhat MK, Bhat S. Cellulose degrading enzymes and their potential industrial applications. Biotechnol Adv 1997;15:583-620. https://doi.org/10.1016/S07349750(97)00006-2.

[92] Swain MR, Natarajan V, Krishnan C. Marine enzymes and microorganisms for bioethanol production. Adv Food Nutr Res 2017;80:181-97. https://doi.org/ 10.1016/bs.afnr.2016.12.003.

[93] Trivedi N, Reddy CRK, Radulovich R, Jha B. Solid state fermentation (SSF)derived cellulase for saccharification of the green seaweed Ulva for bioethanol production. Algal Res 2015;9:48-54. https://doi.org/10.1016/j. algal.2015.02.025.

[94] Trivedi N, Gupta V, Kumar M, Kumari P, Reddy CRK, Jha B. An alkalihalotolerant cellulase from Bacillus flexus isolated from green seaweed Ulva lactuca. Carbohydr Polym 2011;83:891-7. https://doi.org/10.1016/j. carbpol.2010.08.069.

[95] Zhang YH Percival, Himmel ME, Mielenz JR. Outlook for cellulase improvement: screening and selection strategies. Biotechnol Adv 2006;24:452-81. https://doi. org/10.1016/j.biotechadv.2006.03.003.

[96] Bhalla A, Bansal N, Kumar S, Bischoff KM, Sani RK. Improved lignocellulose conversion to biofuels with thermophilic bacteria and thermostable enzymes. Bioresour Technol 2013;128:751-9. https://doi.org/10.1016/j. biortech.2012.10.145.

[97] Choi WY, Han JG, Lee CG, Song CH, Kim JS, Seo YC, et al. Bioethanol production from Ulva pertusa kjellman by high-temperature liquefaction. Chem Biochem Eng Q 2012;26:15-21. https://doi.org/10.2147/NSS.S6844.

[98] Daroch M, Geng S, Wang G. Recent advances in liquid biofuel production from algal feedstocks. Appl Energy 2013;102:1371-81. https://doi.org/10.1016/j. apenergy.2012.07.031.

[99] Rubin EM, Himmel ME, Ding S, Johnson DK, Adney WS. Biomass Recalcitrance: Nature 2007;454:804-7. https://doi.org/10.1126/science.1137016.

[100] Niehaus F, Bertoldo C, Kähler M, Antranikian G. Extremophiles as a source of novel enzymes for industrial application. Appl Microbiol Biotechnol 1999;51: 711-29. https://doi.org/10.1007/s002530051456.

[101] Wilson DB. Cellulases and biofuels. Curr Opin Biotechnol 2009;20:295-9. https:// doi.org/10.1016/j.copbio.2009.05.007.

[102] Ge L, Wang P, Mou H. Study on saccharification techniques of seaweed wastes for the transformation of ethanol. Renew Energy 2011;36:84-9. https://doi.org/ 10.1016/j.renene.2010.06.001.

[103] Hargreaves PI, Barcelos CA, da Costa ACA, Pereira N. Production of ethanol 3G from Kappaphycus alvarezii: evaluation of different process strategies. Bioresour Technol 2013;134:257-63. https://doi.org/10.1016/j.biortech.2013.02.002.

[104] Kim D-H, Lee S-B, Jeong G-T. Production of reducing sugar from Enteromorpha intestinalis by hydrothermal and enzymatic hydrolysis. Bioresour Technol 2014; 161:348-53. https://doi.org/10.1016/j.biortech.2014.03.078.

[105] Kim SW, Hong CH, Jeon SW, Shin HJ. High-yield production of biosugars from Gracilaria verrucosa by acid and enzymatic hydrolysis processes. Bioresour Technol 2015;196:634-41. https://doi.org/10.1016/j.biortech.2015.08.016.

[106] Lee S, Oh Y, Kim D, Kwon D, Lee C, Lee J. Converting carbohydrates extracted from marine algae into ethanol using various ethanolic escherichia coli strains. Appl Biochem Biotechnol 2011;164:878-88. https://doi.org/10.1007/s12010011-9181-7.

[107] Ra CH, Jeong GT, Shin MK, Kim SK. Biotransformation of 5-hydroxymethylfurfural (HMF) by Scheffersomyces stipitis during ethanol fermentation of hydrolysate of the seaweed Gelidium amansii. Bioresour Technol 2013;140: 421-5. https://doi.org/10.1016/j.biortech.2013.04.122.

[108] Jang Sung-Soo. Production of mono sugar from acid hydrolysis of seaweed. Afr J Biotechnol 2012;11:1953-63. https://doi.org/10.5897/AJB10.1681.

[109] Erasmus JH, Cook PA, Coyne VE. The role of bacteria in the digestion of seaweed by the abalone Haliotis midae. Aquaculture 1997;155:377-86. https://doi.org/ 10.1016/S0044-8486(97)00112-9.

[110] Nguyen TH, Ra CH, Sunwoo IY, Jeong GT, Kim SK. Bioethanol production from Gracilaria verrucosa using Saccharomyces cerevisiae adapted to $\mathrm{NaCl}$ or galactose. Bioproc Biosyst Eng 2017;40:529-36. https://doi.org/10.1007/ s00449-016-1718-2.

[111] Walker G, Stewart G. Saccharomyces cerevisiae in the production of fermented beverages. Beverages 2016;2:30. https://doi.org/10.3390/beverages2040030.

[112] Karagöz P, Özkan M. Ethanol production from wheat straw by Saccharomyces cerevisiae and Scheffersomyces stipitis co-culture in batch and continuous system. Bioresour Technol 2014;158:286-93. https://doi.org/10.1016/j. biortech.2014.02.022.

[113] Jin M, Lau M, Balan V, Dale BE. Two-step SSCF to convert AFEX-treated switchgrass to ethanol using commercial enzymes and Saccharomyces cerevisiae 
424A (LNH-ST). Bioresour Technol 2010;101:8171-8. https://doi.org/10.1016/j. biortech.2010.06.026.

[114] Horn SJ, Aasen IM, Emptyvstgaard K. Ethanol production from seaweed extract. $\mathrm{J}$ Ind Microbiol Biotechnol 2000;25:249-54. https://doi.org/10.1038/sj. jim.7000065.

[115] Horn SJ, Aasen IM, Østgaard K. Production of ethanol from mannitol by Zymobacter palmae. J Ind Microbiol Biotechnol 2000;24:51-7. https://doi.org/ 10.1038/sj.jim.2900771.

[116] Kim NJ, Li H, Jung K, Chang HN, Lee PC. Ethanol production from marine algal hydrolysates using Escherichia coli KO11. Bioresour Technol 2011;102:7466-9. https://doi.org/10.1016/j.biortech.2011.04.071.

[117] Khambhaty Y, Mody K, Gandhi MR, Thampy S, Maiti P, Brahmbhatt H, et al. Kappaphycus alvarezii as a source of bioethanol. Bioresour Technol 2012;103: 180-5. https://doi.org/10.1016/j.biortech.2011.10.015.

[118] Choi D, Sim HS, Piao YL, Ying W, Cho H. Sugar production from raw seaweed using the enzyme method. J Ind Eng Chem 2009;15:12-5. https://doi.org/ 10.1016/j.jiec.2008.08.004

[119] Kádár Z, Szengyel Z, Réczey K. Simultaneous saccharification and fermentation (SSF) of industrial wastes for the production of ethanol. Ind Crops Prod 2004;20: 103-10. https://doi.org/10.1016/j.indcrop.2003.12.015.

[120] Cho Y, Kim MJ, Kim SK. Ethanol production from seaweed, Enteromorpha intestinalis, by separate hydrolysis and fermentation (SHF) and simultaneous saccharification and fermentation (SSF) with Saccharomyces cerevisiae. KSBB J 2013;28:366-71. https://doi.org/10.7841/ksbbj.2013.28.6.366.

[121] Tesfaw A, Assefa F. Current trends in bioethanol production by Saccharomyces cerevisiae: substrate, inhibitor reduction, growth variables, coculture, and immobilization. Int Sch Res Not 2014;2014:1-11. https://doi.org/10.1155/2014/ 532852.

[122] Tolieng V, Kunthiphun S, Savarajara A, Tanasupawat S. Diversity of yeasts and their ethanol production at high temperature. J Appl Pharm Sci 2018;8:136-42. https://doi.org/10.7324/JAPS.2018.8221.

[123] Hu N, Yuan B, Sun J, Wang SA, Li FL. Thermotolerant Kluyveromyces marxianus and Saccharomyces cerevisiae strains representing potentials for bioethanol production from Jerusalem artichoke by consolidated bioprocessing. App Microbiol Biotechnol 2012;95:1359-68. https://doi.org/10.1080/ 03602559.2017 .1373397

[124] Goshima T, Tsuji M, Inoue H, Yano S, Hoshino T, Matsushika A. Bioethanol production from lignocellulosic biomass by a novel Kluyveromyces marxianus strain. Biosci Biotechnol Biochem 2013;77:1505-10. https://doi.org/10.1271/ bbb.130173.

[125] Yeon JH, Lee SE, Choi WY, Kang DH, Lee HY, Jung KH. Repeated-batch operation of surface-aerated fermentor for bioethanol production from the hydrolysate of seaweed Sargassum sagamianum. J Microbiol Biotechnol 2011;21:323-31. https://doi.org/10.4014/jmb.1010.10057.

[126] Park JH, Hong JY, Jang HC, Oh SG, Kim SH, Yoon JJ, et al. Use of Gelidium amansii as a promising resource for bioethanol: a practical approach for continuous dilute-acid hydrolysis and fermentation. Bioresour Technol 2012;108: 83-8. https://doi.org/10.1016/j.biortech.2011.12.065.

[127] Mohd Azhar SH, Abdulla R, Jambo SA, Marbawi H, Gansau JA, Mohd Faik AA, et al. Yeasts in sustainable bioethanol production: a review. Biochem Biophys Reports 2017;10:52-61. https://doi.org/10.1016/j.bbrep.2017.03.003.

[128] Zabed H, Faruq G, Sahu JN, Azirun MS, Hashim R, Nasrulhaq Boyce A. Bioethano production from fermentable sugar juice. Sci World J 2014;2014. https://doi.org/ $10.1155 / 2014 / 957102$

[129] Neelakandan T, Usharani G. Optimization and production of bioethanol from cashew apple juice using immobilized yeast cells by Saccharomyces cerevisiae. J Sci Res 2009;4:85-8.

[130] El Sayed WMM, Ibrahim HAH. Evaluation of bioethanol production from Ulva lactuca by Saccharomyces cerevisiae. J Biotechnol Biomater 2016;6. https://doi. org/10.4172/2155-952X.1000226.

[131] Kopsahelis N, Nisiotou A, Kourkoutas Y, Panas P, Nychas GJE, Kanellaki M. Molecular characterization and molasses fermentation performance of a wild yeast strain operating in an extremely wide temperature range. Bioresour Technol 2009;100:4854-62. https://doi.org/10.1016/j.biortech.2009.05.011.

[132] Wu FC, Wu JY, Liao YJ, Wang MY, Shih IL. Sequential acid and enzymatic hydrolysis in situ and bioethanol production from Gracilaria biomass. Bioresour Technol 2014;156:123-31. https://doi.org/10.1016/j.biortech.2014.01.024.

[133] Mutripah S, Meinita MDN, Kang JY, Jeong GT, Susanto AB, Prabowo RE, et al. Bioethanol production from the hydrolysate of Palmaria palmata using sulfuric acid and fermentation with brewer's yeast. J Appl Phycol 2014;26:687-93. https://doi.org/10.1007/s10811-013-0068-6.

[134] Hebbale D, Chandran MDS, Joshi NV, Ramachandra TV. Energy and food security from macroalgae. J Biodivers 2017;8:1-11. https://doi.org/10.1080/ 09766901.2017.1351511.

[135] Carl C, De Nys R, Paul NA. The seeding and cultivation of a tropical species of filamentous Ulva for algal biomass production. PLoS One 2014;9:98700. https:// doi.org/10.1371/journal.pone.0098700.

[136] Guiry MD, Guiry GM. AlgaeBase. World-Wide Electronic Publication. Galway: National University of Ireland; 2013, http://www.algaebase.org.

[137] Dubois M, Gilles KA, Hamilton JK, Rebers PA, Smith F. Colorimetric method for determination of sugars and related substances. Anal Chem 1956;28:350-6. https://doi.org/10.1021/ac60111a017.

[138] Updegraff DM. Semimicro determination of cellulose inbiological materials. Anal Biochem 1969;32:420-4. https://doi.org/10.1016/S0003-2697(69)80009-6.
[139] Lowry OH, Rosebrough NJ, Farr AL, Randall RJ. Protein measurement with the folin phenol reagent. J Biol Chem 1951;193:265-75. https://doi.org/10.1016/ 0304-3894(92)87011-4.

[140] Bligh EG, Dyer WJ. A rapid method of total lipid extraction and purification. Can J Biochem Physiol 1959;37:911-7. https://doi.org/10.1139/y59-099.

[141] Meinita MDN, Hong YK, Jeong GT. Detoxification of acidic catalyzed hydrolysate of Kappaphycus alvarezii (cottonii). Bioproc Biosyst Eng 2012;35:93-8. https:// doi.org/10.1007/s00449-011-0608-x.

[142] Miller GL. Use of dinitrosalicylic acid reagent for determination of reducing sugar. Anal Chem 1959;31:426-8. https://doi.org/10.1021/ac60147a030.

[143] Subba Rao PV, Mantri VA. Indian seaweed resources and sustainable utilization: scenario at the dawn of a new century. Curr Sci 2006;91:164-74. https://doi.org/ 10.1021/Ie201743x.

[144] Chennubhotla VSK, Kaliaperumal N, Kalimuthu S. Seaweed recipes and other practical uses of. Seaweeds 1981;13:9-16.

[145] Kaliaperumal N, Chennubhotla VSK. Sea weed distribution and resources in Kerala coast. Seaweed Res Uliln 1997;19:29-32.

[146] Mishra SSS. Biodiversity of marine benthic algae from intertidal zone of konkan coast. (Maharashtra). Indian J Appl Res 2014;4:1-3. https://doi.org/10.1007/ s11517-014-1207-1.

[147] Pereira N, Almeida MR. A preliminary checklist of marine algae from the Coast of Goa, vol. 43; 2014.

[148] Rath J, Adhikary SP. Marine macro-algae of Orissa, east coast of India. ALGAE 2010;21:49-59. https://doi.org/10.4490/algae.2006.21.1.049.

[149] Thakur MC, Reddy CRK, Jha B. Seasonal variation in biomass and species composition of seaweeds stranded along Port Okha, northwest coast of India. J Earth Syst Sci 2008;117:211-8. https://doi.org/10.1007/s12040-008-0025-y.

[150] Thirumaran G, Anantharaman P. Daily growth rate of field farming seaweed Kappaphycus alvarezii (doty) doty ex P. Silva in vellar estuary. World J Fish Mar Sci 2009:1:144-53.

[151] Lobban CS, Harrison PJ, Lobban CS, Harrison PJ. Morphology, life histories, and morphogenesis. Seaweed Ecol Physiol 2009;1-68. https://doi.org/10.1017/ cbo9780511626210.002.

[152] Rameshkumar S, Rajaram R. Experimental cultivation of invasive seaweed Kappaphycus alvarezii (Doty) Doty with assessment of macro and meiobenthos diversity from Tuticorin coast, Southeast coast of India. Reg Stud Mar Sci 2017;9: 117-25. https://doi.org/10.1016/j.rsma.2016.12.002.

[153] Geetanjah'Deshmukhe VX, Untawale G. Seaweed resources. Indian Ocean A Perspect 2001;2:563.

[154] Fleurence J. Seaweed proteins: biochemical, nutritional aspects and potential uses. Trends Food Sci Technol 1999;10:25-8. https://doi.org/10.1016/S09242244(99)00015-1.

[155] Kang KE, Park DH, Jeong GT. Effects of inorganic salts on pretreatment of Miscanthus straw. Bioresour Technol 2013;132:160-5. https://doi.org/10.1016/ j.biortech.2013.01.012.

[156] Nitsos CK, Matis KA, Triantafyllidis KS. Optimization of hydrothermal pretreatment of lignocellulosic biomass in the bioethanol production process. ChemSusChem 2013;6:110-22. https://doi.org/10.1002/cssc.201200546.

[157] Glicksman M. Utilization of seaweed hydrocolloids in the food industry, vols. 151-152; 1987.

[158] Bixler HJ, Porse H. A decade of change in the seaweed hydrocolloids industry. J Appl Phycol 2011;23:321-35. https://doi.org/10.1007/s10811-010-9529-3.

[159] Cuevas M, Sánchez S, García JF, Baeza J, Parra C, Freer J. Enhanced ethanol production by simultaneous saccharification and fermentation of pretreated olive stones. Renew Energy 2015;74:839-47. https://doi.org/10.1016/j. renene.2014.09.004.

[160] Jmel MA, Anders N, Ben Yahmed N, Schmitz C, Marzouki MN, Spiess A, et al. Variations in physicochemical properties and bioconversion efficiency of Ulva lactuca polysaccharides after different biomass pretreatment techniques. Appl Biochem Biotechnol 2018;184:777-93. https://doi.org/10.1007/s12010-0172588-z.

[161] Prabakaran P, Ravindran AD. A comparative study on effective cell disruption methods for lipid extraction from microalgae. Lett Appl Microbiol 2011;53: 150-4. https://doi.org/10.1111/j.1472-765X.2011.03082.x.

[162] Jahnavi G, Prashanthi GS, Sravanthi K, Rao LV. Status of availability of lignocellulosic feed stocks in India: biotechnological strategies involved in the production of Bioethanol. Renew Sustain Energy Rev 2017;73:798-820. https:// doi.org/10.1016/j.rser.2017.02.018.

[163] Lee J ye, Li P, Lee J, Ryu HJ, Oh KK. Ethanol production from Saccharina japonica using an optimized extremely low acid pretreatment followed by simultaneous saccharification and fermentation. Bioresour Technol 2013;127:119-25. https:// doi.org/10.1016/j.biortech.2012.09.122.

[164] Meinita MDN, Kang JY, Jeong GT, Koo HM, Park SM, Hong YK. Bioethanol production from the acid hydrolysate of the carrageenophyte Kappaphycus alvarezii (cottonii). J Appl Phycol 2012;24:857-62. https://doi.org/10.1007/ s10811-011-9705-0.

[165] Wei N, Quarterman J, Kim SR, Cate JHD, Jin YS. Enhanced biofuel production through coupled acetic acid and xylose consumption by engineered yeast. Nat Commun 2013;4:1-8. https://doi.org/10.1038/ncomms3580.

[166] Jeong GT, Kim SK, Park DH. Detoxification of hydrolysate by reactive-extraction for generating biofuels. Biotechnol Bioproc Eng 2013;18:88-93. https://doi.org/ 10.1007/s12257-012-0417-3.

[167] Yanagisawa M, Kawai S, Murata K. Strategies for the production of high concentrations of bioethanol from seaweeds. Bioengineered 2013;4:224-35. https://doi.org/10.4161/bioe.23396. 
[168] Johnson B, Gopakumar G. Farming of the seaweed Kappaphycus alvarezii in Tamil Nadu coast status and constraints. Mar Fish Inf Serv T\&E 2011;208:1-5.

[169] Wooley R, Ruth M, Sheehan J, Ibsen K, Majdeski H, Galvez A. Lignocellulosic biomass to ethanol process Design and economics utilizing Co-current dilute acid prehydrolysis and enzymatic hydrolysis current and futuristic scenarios. 1999.

[170] Suriyachai N, Weerasaia K, Laosiripojana N, Champreda V, Unrean P. Optimized simultaneous saccharification and co-fermentation of rice straw for ethanol production by Saccharomyces cerevisiae and Scheffersomyces stipitis co-culture using design of experiments. Bioresour Technol 2013;142:171-8. https://doi.org/ 10.1016/j.biortech.2013.05.003.

[171] Siddhanta AK, Prasad K, Meena R, Prasad G, Mehta GK, Chhatbar MU, et al. Profiling of cellulose content in Indian seaweed species. Bioresour Technol 2009; 100:6669-73. https://doi.org/10.1016/j.biortech.2009.07.047.

[172] Kim HM, Wi SG, Jung S, Song Y, Bae HJ. Efficient approach for bioethanol production from red seaweed Gelidium amansii. Bioresour Technol 2015;175 128-34. https://doi.org/10.1016/j.biortech.2014.10.050.

[173] Wang X, Liu X, Wang G. Two-stage hydrolysis of invasive algal feedstock for ethanol fermentation. J Integr Plant Biol 2011;53:246-52. https://doi.org/ 10.1111/j.1744-7909.2010.01024.x.

[174] Borines MG, De Leon RL, McHenry MP. Bioethanol production from farming nonfood macroalgae in Pacific island nations: chemical constituents, bioethanol yields, and prospective species in the Philippines. Renew Sustain Energy Rev 2011;15:4432-5. https://doi.org/10.1016/j.rser.2011.07.109.

[175] Uchida M, Miyoshi T, Kaneniwa M, Ishihara K, Nakashimada Y, Urano N. Production of $16.5 \% \mathrm{v} / \mathrm{v}$ ethanol from seagrass seeds. J Biosci Bioeng 2014;118: 646-50. https://doi.org/10.1016/j.jbiosc.2014.05.017.

[176] Baldan B, Andolfo P, Navazio L, Tolomio C, Mariani P. Cellulose in algal cell wall : an "in situ" localization. Eur J Histochem 2001;45:51-6. https://doi.org/ $10.4081 / 1613$

[177] Mantri VA, Thakur MC, Kumar M, Reddy CRK, Jha B. The carpospore culture of industrially important red alga Gracilaria dura (Gracilariales, Rhodophyta). Aquaculture 2009;297:85-90. https://doi.org/10.1016/j. aquaculture.2009.09.004.

[178] Padhi S, Swain PK, Behura SK, Baidya S, Behera SK, Panigrahy MR. Cultivation of Gracilaria verrucosa (huds) papenfuss in chilika lake for livelihood generation in coastal areas of Orissa state. J Appl Phycol 2011;23:151-5. https://doi.org/ 10.1007/s10811-010-9592-9.

[179] Bruhn A, Dahl J, Nielsen HB, Nikolaisen L, Rasmussen MB, Markager S, et al. Bioenergy potential of Ulva lactuca: biomass yield, methane production and combustion. Bioresour Technol 2011;102:2595-604. https://doi.org/10.1016/j. biortech.2010.10.010.

[180] Junior JN, Massaguer PR De. Thermal degradation kinetics of sucrose, glucose and fructose in sugarcane must for bioethanol production. J Food Process Eng 2006;29:462-77.

[181] Lenihan P, Orozco A, O'neill E, Ahmad MNM, Rooney DW, Walker GM. Dilute acid hydrolysis of lignocellulosic biomass. Chem Eng J 2010;156:395-403. https://doi.org/10.1016/j.cej.2009.10.061.
[182] Rebek J. On the structure of histidine and its role in enzyme active sites. Struct Chem 1990;1:129-31. https://doi.org/10.1007/BF00675792.

[183] Shuler MLF. Bioprocess engineering basic concepts. 2002.

[184] Frankenberger Jr WT, Johanson JB. Effect of $\mathrm{pH}$ on enzyme stability in soils, vol. $14 ; 1982$.

[185] Arroyo-López FN, Orlić S, Querol A, Barrio E. Effects of temperature, pH and sugar concentration on the growth parameters of Saccharomyces cerevisiae, S. kudriavzevii and their interspecific hybrid. Int J Food Microbiol 2009;131:120-7. https://doi.org/10.1016/j.ijfoodmicro.2009.01.035.

[186] Bertolini MC, Ernandes JR, Laluce C. New yeast strains for alcoholic fermentation at higher sugar concentration. Biotechnol Lett 1991;13:197-202. https://doi.org/ 10.1007/BF01025817.

[187] D'Amato D, Corbo MR, Del Nobile MA, Sinigaglia M. Effects of temperature, ammonium and glucose concentrations on yeast growth in a model wine system. Int J Food Sci Technol 2006;41:1152-7. https://doi.org/10.1111/j.13652621.2005.01128.x.

[188] Luo MB, Liu F. Salinity-induced oxidative stress and regulation of antioxidant defense system in the marine macroalga Ulva prolifera. J Exp Mar Biol Ecol 2011; 409:223-8. https://doi.org/10.1016/j.jembe.2011.08.023.

[189] Saranya G, Subashchandran MD, Mesta P, Ramachandra TV. Prioritization of prospective third-generation biofuel diatom strains. Energy, Ecol Environ 2018;3: 338-54. https://doi.org/10.1007/s40974-018-0105-z.

[190] Nielsen MM, Bruhn A, Rasmussen MB, Olesen B, Larsen MM, Møller HB. Cultivation of Ulva lactuca with manure for simultaneous bioremediation and biomass production. J Appl Phycol 2012;24:449-58. https://doi.org/10.1007/ s10811-011-9767-z.

[191] Chopin T, Buschmann AH, Halling C, Troell M, Kautsky N, Neori A, et al. Integrating seaweeds into marine aquaculture systems: a key toward sustainability. J Phycol 2001;37:975-86. https://doi.org/10.1046/j.15298817.2001.01137.x.

[192] Roesijadi G, Copping AE, Huesemann MH, Forster J. Techno-economic feasibility analysis of offshore seaweed farming for bioenergy and biobased products. 2008.

[193] Bui HTT, Luu TQ, Fotedar R. Effects of temperature and $\mathrm{pH}$ on the growth of Sargassum linearifolium and S. Podacanthum in potassium-fortified inland saline water. Am J Appl Sci 2018;15:186-97. https://doi.org/10.3844/ ajassp.2018.186.197.

[194] Khan SI, Satam SB. Seaweed mariculture: scope and potential in India. Aquac Asia 2003; VIII:26-9.

[195] Mamatha BS, Namitha KK, Senthil A, Smitha J, Ravishankar GA. Studies on use of Enteromorpha in snack food. Food Chem 2007;101:1707-13. https://doi.org/ 10.1016/j.foodchem.2006.04.032.

[196] Adenle AA, Haslam GE, Lee L. Global assessment of research and development for algae biofuel production and its potential role for sustainable development in developing countries. Energy Policy 2013;61:182-95. https://doi.org/10.1016/j. enpol.2013.05.088. 